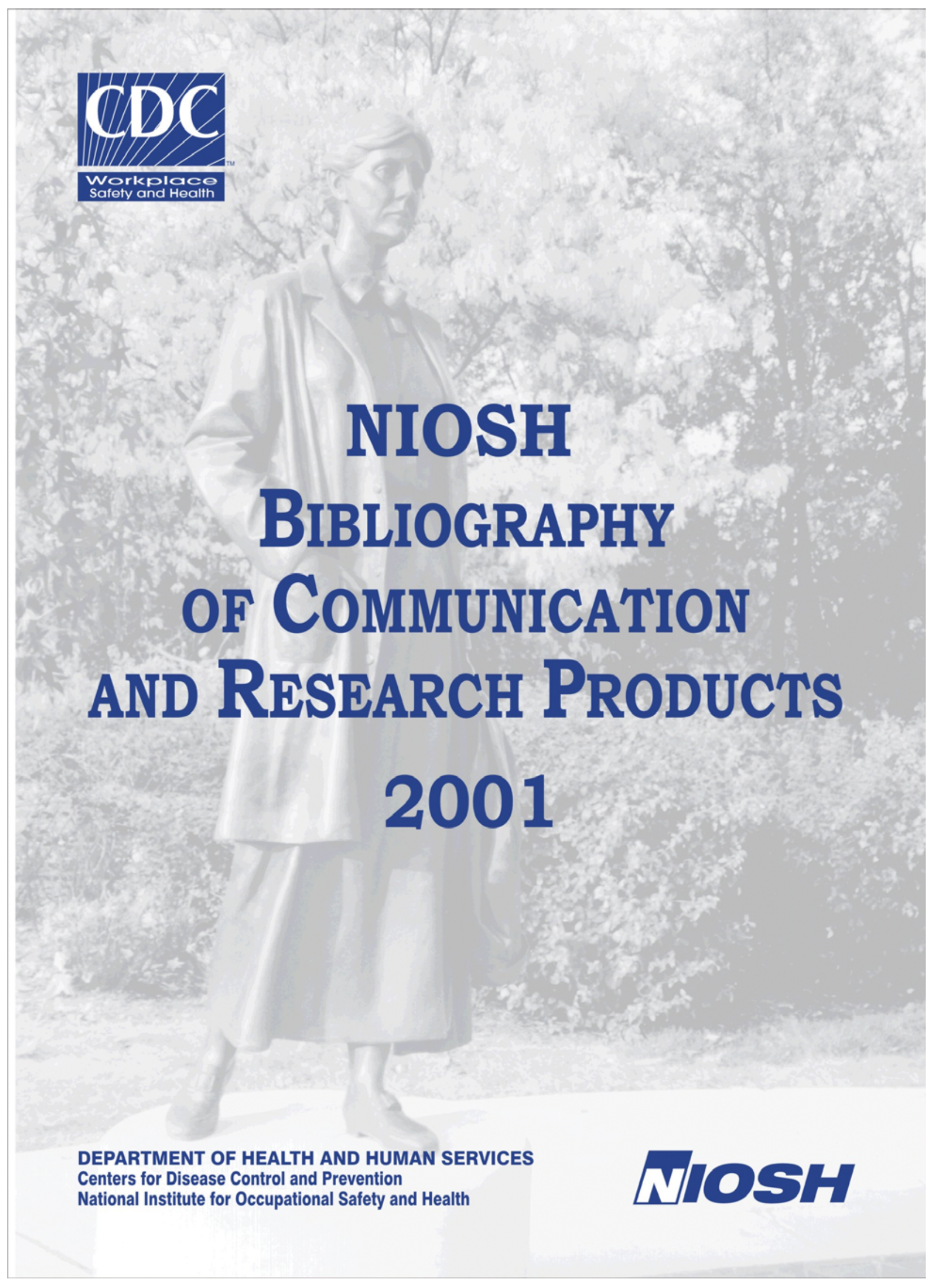




\section{NIOSH BIBLIOGRAPHY OF COMMUNICATION AND RESEARCH PRODUCTS}

\section{1}

A Listing of NIOSH Publications for Calendar Year 2001

Department of Health and Human Services

Centers for Disease Control and Prevention

National Institute for Occupational Safety and Health Washington DC

May 2002 


\section{FOREWORD}

Last year was one of the most extraordinary in our 31-year history. The attacks of September 11, as well as the subsequent anthrax events, highlighted the importance of worker safety and health, perhaps more so than any other time. NIOSH was challenged to address these emergencies while retaining focus on its core mission. These events emphasized the need for reliable data that is communicated clearly and effectively.

The research and communication products listed in this bibliography are the result of the outstanding efforts of NIOSH and its partners to produce good science that is usable by workers, employers, the public, and the occupational safety and health community. NIOSH remains dedicated to preventing work related injuries and disease and to meeting any new and future challenges. We hope you will have the opportunity to explore these products further.

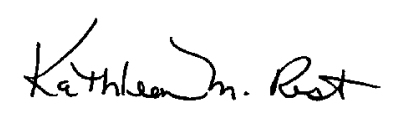

Kathleen M. Rest, Ph.D., M.P.A.

Acting Director

National Institute for Occupational Safety and Health 


\section{CONTENTS}

I. Journal Articles $\ldots \ldots \ldots \ldots \ldots \ldots \ldots \ldots \ldots \ldots \ldots \ldots \ldots$

II. Book Chapters/Proceedings/Abstracts/Technical Papers $\ldots \ldots \ldots 27$

III. NIOSH Numbered Publications $\ldots \ldots \ldots \ldots \ldots \ldots \ldots \ldots \ldots$

IV. Electronic and Media Products $\ldots \ldots \ldots \ldots \ldots \ldots \ldots \ldots \ldots$

V. Hazard Evaluation and Technical Assistance Reports ........ 61

VI. Fatality Assessment and Control Evaluations ........... 67

VII. Technology News $\ldots \ldots \ldots \ldots \ldots \ldots \ldots \ldots \ldots \ldots \ldots, 73$

VIII. Control Technology Reports $\ldots \ldots \ldots \ldots \ldots \ldots \ldots \ldots \ldots \ldots \ldots$ 


\section{JOURNAL ARTICLES}

Abell MT, Woebkenberg ML, Armstrong TW, Stenzel MR [2001]. Research recommendations of the NORA exposure assessment methods team. Appl Occup Environ Hyg 16(2):331-333.

Alexander WK, Briggs GB, Still KR, Jederberg WW, MacMahon K, Baker WH, Mackerer C [2001]. Toxicity of 2,6-Di-tert-butyl-4-Nitrophenol (DBNP). Appl Occup Environ Hyg 16(4):487-495.

Antonini JM, Roberts JR, Clarke RW [2001]. Strain-related differences of nonspecific respiratory defense mechanisms in rats using a pulmonary infectivity model. Inhal Toxicol 13(1):85-102.

Antonini JM, Roberts JR, Clarke RW, Yang H-M, Barger MW, Ma JYC, Weissman DN [2001]. Effect of age on respiratory defense mechanisms. Chest 120(1):240-249.

Ashley KE [2001]. Analytical instrument performance criteria: international standard procedure for the extraction of metal compounds having soluble threshold limit values. Appl Occup Environ Hyg 16(9):850-853.

Ashley KE, Andrews RN, Cavazos L, Demange M [2001]. Ultrasonic extraction as a sample preparation technique for elemental analysis by atomic spectrometry. J Analyt Atomic Spectrom 16(10):1147-1153.

Ashley KE, Wise TJ, Mercado W, Parry DB [2001]. Ultrasonic extraction and field-portable anodic stripping voltammetric measurement of lead in dust wipe samples. J Hazard Mater $83(1-2): 41-50$.

Baker R, Brockhaus A, Boucier D, Chapman L, Collins J, Goldenhar L, Heaney C, Katz T, Landsbergis P, Martonik J, Most I, Schneider S, Scharf T, Sinclair R. May 2000 supplement on preventing occupational injuries. [letter; comment]. Am J Prev Med 20(4):308-309.

Ballard TJ, Calvert GM [2001]. Surveillance of acute occupational pesticide-related illness and injury: the US experience. Ann 1st Super Sanita 37(2):175-179.

Bang KM, Kim JH [2001]. Prevalence of cigarette smoking by occupation and industry in the United States. Am J Ind Med 40:233-239.

Baron PA [2001]. Measurement of airborne fibers: a review. Ind Health 39(2):39-50. 


\section{Journal Articles}

Bartley DL [2001]. Definition and assessment of sampling and analytical accuracy. Ann Occup Hyg 45(5):357-364.

Beeckman LF, Wang ML, Petsonk EL, Wagner GR [2001]. Rapid declines in FEV and subsequent respiratory symptoms, illnesses, and mortality in coal miners in the United States. Am J Respir Crit Care Med 163:633-639.

Bena JF, Bailer AJ, Park RH, Halperin WE [2001]. A graphical analysis of mortality rates and years of potential life lost. Hum Ecol Risk Assess 7:1843-1857.

Bensyl DM, Moran K, Conway GA [2001]. Factors associated with pilot fatality in work-related aircraft crashes, Alaska, 1990-1999. Am J Epidemiol 154(11):1037-1042.

Biagini RE, Krieg EF Jr., Pinkerton LE, Hamilton RG [2001]. Receiver operating characteristics analyses of Food and Drug Administration-cleared serological assays for natural rubber latexspecific immunoglobulin E antibody. Clin Diagn Lab Immunol 8(6):1145-1149.

Bibb JA, Nishi A, O’Callaghan JP, Ule J, Lan M, Snyder GL, Horiuchi A, Saito T, Hisanaga S-I, Czernik AJ, Nairn AC, Greengard P [2001]. Phosphorylation of protein phosphatase inhibitor-1 by Cdk5. J Biol Chem 276(17):14490-14497.

Bobick TG, Belard J, Hsiao H, Wassell JT [2001]. Physiological effects of back belt wearing during asymmetric lifting. Appl Ergon 32(6):541-547.

Boden LI, Biddle EA, Spieler EA [2001]. Social and economic impacts of workplace illness and injury: current and future directions for research. Am J Ind Med 40:398-402.

Boeniger MF [2001]. Dermal exposure research—report on the technical sessions at the 2001 AIHCE. The Synergist, pp.19-21.

Boeniger MF, Lummus ZL, Biagini RE, Bernstein DI, Swanson MC, Reed C, Massoudi M [2001]. Exposure to protein aeroallergens in egg processing facilities. Appl Occup Environ Hyg 16(6):660-670.

Bowman JD, Thomas DC [2001]. Are children living near high-voltage power lines at increased risk of acute lymphoblastic leukemia? [letter to the editor]. Am J Epidemiol 153(6):615-617.

Bowyer JF, Holson RR, Miller DB, O'Callaghan JP [2001]. Phenobarbital and dizocilpine can block methamphetamine-induced neurotoxicity in mice by mechanisms that are independent of thermoregulation. Brain Res 919(1):179-183.

Brancazio L, Franz GN, Petsonk EL, Frazer DG [2001]. Lung area-volume models in relation to the recruitment-derecruitment of individual lung units. Ann Biomed Eng 29(3):252-262. 


\section{Journal Articles}

Burchiel SW, Luster MI [2001]. Signaling by environmental polycyclic aromatic hydrocarbons in human lymphocytes. Clin Immunol 98(1):2-10.

Campbell DL, Coffey CC, Lenhart FS [2001]. Respiratory protection as a function of respirator fitting characteristics and fit-test accuracy. Am Ind Hyg Assoc J 62:36-44.

Capelli-Schellpfeffer M, Kalina C, Toney M, Mitchell J, Lee RC [2001]. Partnerships for electrical safety. IEEE Ind Appl 7(3):17-22.

Castranova V, Ma JYC, Yang H-M, Antonini JM, Butterworth L, Barger MW, Roberts J, Ma JKH [2001]. Effect of exposure to diesel exhaust particles on the susceptibility of the lung to infection. Environ Health Perspect 109(4):609-612.

Cecala AB, Organiscak JA, Heitbrink WA [2001]. Dust underfoot: enclosed cab floor heaters can significantly increase operator's respirable dust exposure. Rock Products 104(4):39-44.

CDC (Centers for Disease Control and Prevention) [2001]. Baler and compactor-related deaths in the workplace-United States, 1992-2000. MMWR 50(16):309-313.

CDC (Centers for Disease Control and Prevention) [2001]. Updated U.S. Public Health Service guidelines for the management of occupational exposures to HBV, HCV, and HIV and recommendations for postexposure prophylaxis. MMWR 50 (RR-11):1-67.

CDC (Centers for Disease Control and Prevention) [2001]. Nonfatal occupational injuries treated in hospital emergency departments-United States, 1998. MMWR 50(16):313-317.

CDC (Centers for Disease Control and Prevention) [2001]. Fatal occupational injuries-United States, 1980-1997. MMWR 50(16):317-320.

CDC (Centers for Disease Control and Prevention) [2001]. Outbreak of legionnaires' disease among automotive plant workers-Ohio. MMWR 50:(18):357-359.

CDC (Centers for Disease Control and Prevention) [2001]. Evaluation of Bacillus anthracis contamination inside the Brentwood Mail Processing and Distribution Center-District of Columbia, October 2001. MMWR 50(50):1129-1133.

CDC (Centers for Disease Control and Prevention ) [2001]. Pesticide-related illnesses associated with the use of plant growth regulator-Italy, 2001. MMWR 50(39):845-847.

Chapman LJ, Taveira AD, Josefsson KG, Hard DL [2001]. A hazard analysis of three silage storage methods for dairy cattle. Hum Ecol Risk Assess 7(7):1895-1907. 


\section{Journal Articles}

Cheever KL, Swearengin TF, Edwards RM, Nelson BK, Werren DM, Conover DL, DeBord DG [2001]. 2-Methoxyethanol metabolism, embryonic distribution, and macromolecular adduct formation in the rat: the effect of radiofrequency radiation-induced hyperthermia. Toxicol Lett 122(1):53-67.

Chen F, Castranova V, Shi X [2001]. New insights into the role of nuclear factor- $\kappa \mathrm{B}$ in cell growth regulation. Am J Pathol 159(2):387-397.

Chen F, Ding M, Castranova V, Shi X [2001]. Carcinogenic metals and NF- $\kappa B$ activation. Mol Cell Biochem 222(1-2):159-171.

Chen F, Lu Y, Zhang Z, Vallyathan V, Ding M, Castranova V, Shi X [2001]. Opposite effect of NF- $\kappa \mathrm{B}$ and c-Jun N-terminal kinase on p53-independent GADD45 induction by arsenite. J Biol Chem 276(14):11414-11419.

Chen F, Vallyathan V, Castranova V, Shi X [2001]. Cell apoptosis induced by carcinogenic metals. Mol Cell Biochem 222(1-2):183-188.

Chen F, Zhang Z, Leonard SS, Shi X [2001]. Contrasting roles of NF- $\kappa$ B and JNK in arseniteinduced p53-independent expression of GADD45 $\alpha$. Oncogene 20(27):3585-3589.

Chen G, Jenkins L, Marsh S, Johnston JJ [2001]. Work-related and non work-related injury deaths in the U.S.: a comparative study. Hum Ecol Risk Assess 7(7):1859-1868.

Chen GX, Hendricks KJ [2001]. Nonfatal occupational injuries among African-American women by industrial group. J Saf Res 32:75-84.

Chen W, Zhuang Z, Attfield MD, Chen BT, Gao P, Harrison JC, Fu C, Chen J-Q, Wallace WE [2001]. Exposure to silica and silicosis among tin miners in China: exposure response analyses and risk assessment. Occup Environ Med 58(1):31-37.

Conway GA [2001]. The future of arctic and circumpolar health. Int J Circumpolar Health 60(4):724-728.

Conway GA, Lincoln JM, Husberg BJ, Manwaring JC, Bensyl DM, Choromanski DM. [2001]. Alaska's model program for occupational injury prevention: applying surveillance for effective public health practice. Int J Circumpolar Health 60(4):714-723.

Conway GA, Lincoln JM, Husberg BJ, Bensyl DM, Manwaring JC [2001]. Occupational injury research and prevention in Alaska. Arctic Research of the United States 15(4):14-26.

Dababneh AJ, Swanson NG, Shell RL [2001]. Impact of added rest breaks on the productivity and well being of workers. Ergonomics 44(2):164-174. 


\section{Journal Articles}

Das R, Steege AL, Baron S, Beckman J, Harrison R [2001]. Pesticide-related illness among migrant farm workers in the United States - special issue on international pesticide use.

Int J Occup Med Environ Health 7(1):303-312.

Davis RR, Newlander JK, Ling XB, Cortopassi GA, Krieg EF Jr., Erway LC [2001]. Genetic basis for susceptibility to noise-induced hearing loss in mice. Hear Res 155(1-2):82-90.

Deitchman S, Bang KM [2001]. The epidemiology of occupational injuries and illnesses of health care workers. Clin Occup and Environ Med 1(2):201-216.

Deitchman S, Dembe AE, Himmelstein J [2001]. Advent of occupational health services research. Am J Ind Med 40(3):291-294.

Deitchman S, Sokas R [2001]. Glanders in a military research microbiologist. N Engl J Med 345(22): 1644.

Demchuk E, Singh H [2001]. Statistical thermodynamics of hindered rotation from computer simulations. Mol Physics 99(8):627-636.

Dick RB, Steenland K, Krieg EF Jr., Hines CJ [2001]. Evaluation of acute sensory-motor effects and test sensitivity using termiticide workers exposed to chlorpyrifos. Neurotoxicol Teratol 23(4):381-393.

Ding M, Shi X, Lu Y, Huang C, Leonard S, Roberts J, Antonini J, Castranova V, Vallyathan V [2001]. Induction of activator protein-1 through reactive oxygen species by crystalline silica in JB6 cells. J Biol Chem 276(12):9108-9114.

Dokka S, Shi X, Leonard S, Wang L, Castranova V, Rojanasakul Y [2001]. Interleukin-10mediated inhibition of free radical generation in macrophages. Am J Physiol Lung Cell Mol Physiol 6(280):L1196-L1202.

Dong RG, Rakheja S, Schopper AW, Han B, Smutz WP [2001]. Hand-transmitted vibration and biodynamic response of the human hand-arm: a critical review. Crit Rev Biomed Eng 29(4):393-439.

Drake P, Rojas M, Reh C, Mueller C, Jenkins M [2001]. Occupational exposure to airborne mercury during gold mining operations near El Callao, Venezuela. Int Arch Occup Environ Health 74:206-212.

England E, Key-Schwartz RJ, Lesage J, Carlton G, Streicher R, Song R [2001]. Erratum to "Comparison of sampling methods for monomer and polyisocyanates of 1,6-hexamethylene diisocyanate during spray finishing operations" [Appl Occup Env Hyg 15(6):472-478]. Appl Occup Envir Hyg 16(1):1. 


\section{Journal Articles}

Esterhuizen TM, Hnizdo E, Rees D [2001]. Occurrence and causes of occupational asthma in South Africa: results from SORDSA's occupational asthma registry, 1997-1999. S Afr Med J 91(6):509-513.

Esterhuizen TM, Hnizdo E, Rees D, Lalloo UG [2001]. Setting the scene for SORDSA: the importance of occupational respiratory disease surveillance in South Africa [editorial]. S Afr Med J 91(6):498-499.

Esterhuizen TM, Rees D, Hnizdo E, Lalloo UG, Kielkowski D, van Schalkwyk EM, White N, Smith FC, Hoggins B, Curtis T [2001]. Occupational respiratory diseases in South Africa: results from SORDSA, 1997-1999. S Afr Med J 91(6):502-508.

Estill CF, Spencer AB, McCammon JB, Mickelsen RL, Johnston OE, Votaw AL, Flesch JP [2001]. Hazard controls: controlling chemical hazards during the application of artificial fingernails. Appl Occup Environ Hyg 16(5):509-511.

Eversull E, Solomonow M, Zhou B, Baratta RV, Zhu M [2001]. Neuromuscular neutral zones sensitivity to lumbar displacement rate. Clin Biomech 16:102-113.

Ewers LM, Tapp LC [2001]. Case studies: endotoxin exposures during potato processing. Appl Occup Environ Hyg 16:(12):1079-1087.

Faulkner K, Landsittel D, Hendricks S [2001]. Robbery characteristics and employee injuries in convenience stores. Am J Ind Med 40:703-709.

Fedan JS, Cutler P [2001]. Hard metal-induced disease: effects of metal cations in vitro on guinea pig isolated airways. Toxicol Appl Pharmacol 174(3):199-206.

Fedan JS, Van Scott MR, Johnston RA [2001]. Pharmacological techniques for the in vitro study of airways. J Pharmacol Toxicol Methods 45(2):159-174.

Feyer AM, Williamson AM, Stout N, Driscoll T, Usher H, Langley JD [2001]. Comparison of work-related fatal injuries in the United States, Australia, and New Zealand: method and overall findings. Inj Prev 7:22-28.

Fischer FM, Morata TC, Latorre MR, Krieg EF Jr., Fiorini AC, Colacioppo S, Gozzoli L, Padrao MA, Zavariz C, Lieber R, Wallingford KM, Cesar CLG [2001]. Effects of environmental and organizational factors on the health of shiftworkers of a printing company. J Occup Environ Med 43(10):882-889.

Flint MS, Valosen JM, Johnson EA, Miller DB, Tinkle SS [2001]. Restraint stress applied prior to chemical sensitization modulates the development of allergic contact dermatitis differently than restraint prior to challenge. J Neuroimmunol 113(1):72-80. 


\section{Journal Articles}

Flint MS, Tinkle SS [2001]. C57BL/6 mice are resistant to acute restraint modulation of cutaneous hypersensitivity. Toxicol Sci 62(2):250-256.

Forgeron S, Mark C, Forrester DJ [2001]. Standardisation of geological and geomechanical assessment at underground coal mines in Canada. Canadian Institute of Mining, Metallurgy and Petroleum Bulletin July:83-90.

Gallagher S, Hamrick CA, Cornelius KM, Redfern MS [2001]. The effects of restricted workspace on lumbar spine loading. Occup Ergon 2:201-213.

Gallucci RM, Sugawara T, Yucesoy B, Berry Ann K, Simeonova PP, Matheson JM, Luster MI [2001]. Interleukin-6 treatment augments cutaneous wound healing in immunosuppressed mice. J Interferon Cytokine Res 21:603-609.

Gao N, Keane MJ, Ong T, Ye J, Miller WE, Wallace WE [2001]. Effects of phospholipid surfactant on apoptosis induction by respirable quartz and kaolin in NR8383 rat pulmonary macrophages. Toxicol Appl Pharmacol 175(3):217-225.

Giorcelli RJ, Hughes RE, Wassell JT, Hsiao H [2001]. The effect of wearing a back belt on spine kinematics during asymmetric lifting of large and small boxes. Spine 26(16):1794-1789.

Goldenhar L, LaMontagne A, Katz T, Heaney C, Landsbergis P [2001]. The intervention research process in occupational safety and health: an overview from the National Occupational Research Agenda intervention effectiveness research team. J Occup Environ Med 43(7):616-622.

Greim H, Borm P, Schins R, Donaldson K, Driscoll K, Hartwig A, Kuempel E, Oberdorster G, Speit G [2001]. Toxicity of fibers and particles-report of the workshop held in Munich, Germany, October 26-27, 2000. Inhal Toxicol 13:737-75.

Gressel MG, Votaw AL, Hagedorn RT, Flesch JP [2001]. Hazard controls: controlling formaldehyde exposures during embalming. Appl Occup Environ Hyg 16(4):438.

Hartley D, Biddle EA [2001]. Will risks to older workers change in the 21st century? Hum Ecol Risk Assess 7(7):1885-1894.

Heitbrink WA, Flesch JP [2001]. Hazard controls: control of paint overspray in autobody repair shops. Appl Occup Environ Hyg 16(8):780.

Hendricks K, Adekoya N [2001]. Non-fatal animal related injuries to youth occurring on farms in the United States, 1998. Inj Prev 7:307-311. 


\section{Journal Articles}

Henneberger PK, Cumro D, Deubner D, Kent MS, McCawley MA, Kreiss K [2001]. Beryllium sensitization and disease among long-term and short-term workers in a beryllium ceramics plant. Int Arch Occup Environ Health 74:167-176.

Hewett P [2001]. Misinterpretation and misuse of exposure limits. Appl Occup Environ Hyg $16(2): 251-256$.

Higgins DN, Casini VJ, Bost P, Johnson W, Rautiainen R [2001]. The Fatality Assessment and Control Evaluation program's role in the prevention of occupational fatalities. Inj Prev 7(Suppl I):i27-33.

Hines CJ, Deddens JA [2001]. Determinants of chlorpyrifos exposures and urinary 3,5,6trichloro-2-pyridinol levels among termiticide applicators. Ann Occup Hyg 45(4):309-321.

Hines CJ, Deddens JA, Tucker SP, Hornung RW [2001]. Distributions and determinants of pre-emergent herbicide exposures among custom applicators. Ann Occup Hyg 45(3):227-239.

Hnizdo E, Esterhuizen TM, Rees D, Lalloo UG [2001]. Occupational asthma as identified by the surveillance of work-related and occupational respiratory disease programme in South Africa. Clin Exp Allergy 31(1):32-39.

Hsiao H, Simeonov P [2001]. Preventing falls from roofs: critical review. Ergonomics 44(5): 537-561.

Huang C, Ding M, Li J, Leonard SS, Rojanasakul Y, Castranova V, Vallyathan V, Ju G, Shi X [2001]. Vanadium-induced nuclear factor of activated T cells activation through hydrogen peroxide. J Biol Chem 276(25):22397-22403.

Huang C, Li J, Ding M, Costa M, Castranova V, Vallyathan V, Ju G, Shi X [2001]. Transactivation of RARE and GRE in the cellular response to arsenic. Mol Cell Biochem 222(1-2):119-125.

Huang C, Li J, Costa M, Zhang Z, Leonard SS, Castranova V, Vallyathan V, Ju G, Shi X [2001]. Hydrogen peroxide mediates activation of nuclear factor of activated T cells (NFAT) by nickel subsulfide. Cancer Res 61(22):8051-8057.

Huang C, Li J, Ding M, Leonard SS, Wang L, Castranova V, Vallyathan V, Shi X [2001]. UV induces phosphorylation of protein kinase B (Akt) at Ser-473 and Thr-308 in mouse epidermal C1 41 cells through hydrogen peroxide. J Biol Chem 276(43):40234-40240.

Huang C, Li J, Ding M, Wang L, Shi X, Castranova V, Vallyathan V, Ju G, Costa M [2001]. Arsenic-induced NF $\kappa$ B transactivation through Erks- and JNKs-dependent pathways in mouse epidermal JB6 cells. Mol Cell Biochem 222(1-2):29-34. 


\section{Journal Articles}

Huang C, Ma W-Y, Ding M, Li J, Shi X, Castranova V, Vallyathan V, Bode AM, Dong Z [2001]. Involvement of sphingomyelinase in insulin-induced phosphatidylinositol 3-kinase activation. FASEB J 15(6):1113-1114.

Huang C, Zhang Q, Li J, Shi X, Castranova V, Ju G, Costa M, Dong Z [2001]. Involvement of Erks activation in cadmium-induced AP-1 transactivation in vitro and in vivo. Mol Cell Biochem 222(1-2):141-147.

Huang S-H, Hubbs AF, Stanley CF, Vallyathan V, Schnabel PC, Rojanasakul Y, Ma JKH, Banks DE, Weissman DN [2001]. Immunoglobulin responses to experimental silicosis. Toxicol Sci 59(1):108-117.

Hubbs AF, Minhas NS, Jones W, Greskevitch M, Battelli LA, Porter DW, Goldsmith WT, Frazer D, Landsittel DP, Ma JYC, Barger M, Hill K, Schwegler-Berry D, Robinson VA, Castranova V [2001]. Comparative pulmonary toxicity of 6 abrasive blasting agents. Toxicol Sci 61(1):135-143.

Hudock SD, Wurzelbacher SJ, Reed LD, Hales TR, Siegfried KV [2001]. A precursor to ergonomics best practices for the shipyard industries. J Ship Production 17(3):145-150.

Huffman LJ, Judy DJ, Brumbaugh K, Frazer DG, Reynolds JS, McKinney WG, Goldsmith WT [2001]. Hyperthyroidism increases the risk of ozone-induced lung toxicity in rats. Toxicol Appl Pharmacol 173(1):18-26.

Jackson LL [2001]. Non-fatal occupational injuries and illnesses treated in hospital emergency departments in the United States. Inj Prev 7(Suppl I):i21-26.

Joseph P, Muchnok TK, Klishis ML, Roberts JR, Antonini JM, Whong WZ, Ong TM [2001]. Cadmium-induced cell transformation and tumorigenesis are associated with transcriptional activation of c-fos, c-jun, and c-myc proto-oncogenes: role of cellular calcium and reactive oxygen species. Toxicol Sci 61(2):295-303.

Joseph P, Muchnok T, Ong T-M [2001]. Gene expression profile in BALB/c-3T3 cells transformed with beryllium sulfate. Mol Carcinog 32(1):28-35.

Kagan VE, Kozlov AV, Tyurina YY, Shvedova AA, Yalowich JC [2001]. Antioxidant mechanisms of nitric oxide against iron-catalyzed oxidative stress in cells. Antioxidants \& Redox Signal 3(2):189-202.

Kagan VE, Kuzmenko AI, Tyurina YY, Shvedova AA, Matsura T, Yalowich JC [2001]. Pro-oxidant and antioxidant mechanisms of etoposide in HL-60 cells: role of myeloperoxidase. Cancer Res 61(21):7777-7784. 


\section{Journal Articles}

Kang JL, Lee HS, Pack IS, Leonard S, Castranova V [2001]. Iron tetrakis (N-methyl-4'-pyridyl) porphyrinato (FeTMPyP) is a potent scavenging antioxidant and an inhibitor of stimulantinduced NF- $\mathrm{KB}$ activation of raw 264.7 macrophages. J Toxicol Environ Health A 64(4):291-310.

Kang JL, Pack IS, Hong SM, Lee HS, Hah JS, Nam W, Leonard S, Castranova V [2001]. Zinc tetrakis(N-methyl-4'-pyridyl) porphyrinato is an effective inhibitor of stimulant-induced activation of RAW 264.7 cells. Toxicol Appl Pharmacol 172(2):140-149.

Katz AJ, Chiu A, Beaubier J, Shi X [2001]. Combining drosophila melanogaster somaticmutation-recombination and electron-spin-resonance-spectroscopy data to interpret epidemiologic observations on chromium carcinogenicity. Mol Cell Biochem 222(1-2):61-68.

Kelleher PC, Martyny JW, Mroz MM, Maier LA, Ruttenber JA, Young DA, Newman LS [2001]. Beryllium particulate exposure and disease relations in a beryllium machining plant. $\mathrm{J}$ Occup Environ Med 43(3):238-249.

Keshava C, McCanlies EC, Keshava N, Wolff MS, Weston A [2001]. Distribution of HER2 ${ }^{\mathrm{V} 655}$ genotypes in breast cancer cases and controls in the United States. Cancer Lett 173:37-41.

Keshava N, Zhou G, Spruill M, Ensell M, Ong T-M [2001]. Carcinogenic potential and genomic instability of beryllium sulphate in BALB/c-3T3 cells. Mol Cell Biochem 222(1-2):69-76.

Kittasamy NK, Buchholz B [2001]. An ergonomic evaluation of excavating operations: a pilot study. Appl Occup Environ Hyg 16(7):723-726.

Klandorf H, Rathore DS, Iqbal M, Shi X, Van Dyke K [2001]. Accelerated tissue aging and increased oxidative stress in broiler chickens fed allopurinol. Comp Biochem Physiol Toxicol Pharmacol 129(2):93-104.

Konecny R, Leonard S, Shi X, Robinson V, Castranova V [2001]. Reactivity of free radicals on hydroxylated quartz surface and its implications for pathogenicity of silicas: experimental and quantum mechanical study. J Environ Pathol Toxicol Oncol 20(Suppl 1):119-132.

Kowalski KM, Vaught C [2001]. The safety and health of emergency workers. J Contingencies Crisis Mgt 9(3):138-143.

Krewski D, Byus CV, Glickman BW, Lotz WG, Mandeville R, McBride ML, Prato FS, Weaver DF [2001]. Potential health risks of radiofrequency fields from wireless telecommunication devices. J Toxicol Environ Health B Crit Rev 4(1):1-143. 


\section{Journal Articles}

Krewski D, Byus CV, Glickman BW, Lotz WG, Mandeville R, McBride ML, Prato FS, Weaver DF [2001]. Update: recent advances in research on radiofrequency field and health. J Toxicol Environ Health B Crit Rev 4(1):145-159.

Krieg EF Jr., Chrislip DW, Letz RE, Otto DA, Crespo CJ, Brightwell WS, Ehrenberg RL [2001]. Neurobehavioral test performance in the third National Health and Nutrition Examination Survey. Neurotoxicol Teratol 23(6):569-589.

Kuempel ED, O'Flaherty EJ, Stayner LT, Smith RJ, Green FHY, Vallyathan V [2001]. A biomathematical model of particle clearance and retention in the lungs of coal miners: part I. Model development. Regul Toxicol Pharmacol 34(1):69-87.

Kuempel ED, Tran CL, Bailer AJ, Porter DW, Hubbs AF, Castranova V [2001]. Biological and statistical approaches to predicting human lung cancer risk from silica. J Environ Pathol Toxicol Oncol 20(Suppl 1):15-32.

Kuempel ED, Tran CL, Bailer AJ, Smith RJ, Dankovic DA, Stayner LT [2001]. Methodological issues of using observational human data in lung dosimetry models for particulates. Sci Total Environ 274(1-3):67-77.

Kuempel ED, Tran CL, Smith RJ, Bailer AJ [2001]. A biomathematical model of particle clearance and retention in the lungs of coal miners: part II. Evaluation of variability and uncertainty. Regul Toxicol Pharmacol 34:88-101.

Kwong K, Wu Z-X, Kashon ML, Krajnak KM, Wise PM, Lee L-Y [2001]. Chronic smoking enhances tachykinin synthesis and airway responsiveness in guinea pigs. Am J Respir Cell Mol Biol 25(3):299-305.

Lacerda ABM, Morata TC, Fiorini AC [2001]. Characterization of sound pressure levels in fitness centers and complaints from instructors. Rev Bras Otorrinolaringol 65(5):656-659.

Landsittel DP, Murphy DJ, Kiernan NE, Hard DL, Kassab C [2001]. Evaluation of the effectiveness of educational interventions in the Pennsylvania central region farm safety pilot project. Am J Ind Med 40(2):145-152.

Legault ML, Murphy DJ [2001]. Evaluation of the agricultural safety and health best management practices manual. J Agric Saf Health 6(2):141-153.

Lentz TJ [2001]: The A-B-Cs of OELs - a discussion of occupational exposure limits. The Synergist Oct:17-26. 


\section{Journal Articles}

Lentz TJ, Sieber WK, Jones JH, Piacitelli GM, Catlett LR [2001]. Surveillance of safety and health programs and needs in small U.S. businesses. Appl Occup Environ Hyg 16(11):1016-1021.

Lentz TJ, Smith S, Akbar-Khanzadeh F, Bracker AL, Herrick RF, Weems WH, Greife AL [2001]. Safety and health challenges and resources for small businesses. ACGIH Today 9(1):19.

Lewis DM, Janotka E, Whitmer MP, Bledsoe TA [2001]. Detection of microbial antigens in metal working fluids. Int Biodeterioration Biodegradation 47(2):89-94.

Li H, Chen Q, Li S, Yao W, Li L, Shi X, Wang L, Castranova V, Vallyathan V, Ernst E, Chen C [2001]. Effect of Cr(VI) exposure on sperm quality: human and animal studies. Ann Occup Hyg 45(7):505-511.

Lincoln JM, Husberg BJ, Conway GA [2001]. Improving safety in the Alaskan commercial fishing industry. Int J Circumpolar Health 60:705-713.

Little AR, O'Callaghan JP [2001]. Astrogliosis in the adult and developing CNS: is there a role for proinflammatory cytokines? Neurotoxicology 39:1-13.

Liu K, Husler J, Ye J, Leonard SS, Cutler D, Chen F, Wang S, Zhang Z, Ding M, Wang L, Shi X [2001]. On the mechanism of $\mathrm{Cr}(\mathrm{VI})$-induced carcinogenesis: dose dependence of uptake and cellular responses. Mol Cell Biochem 222(1-2):221-229.

Liu KJ, Shi X [2001]. In vivo reduction of chromium(VI) and its related free radical generation. Mol Cell Biochem 222(1-2):41-47.

Loos G, Diether J [2001]. Occupational safety and health training on the internet. AAOHN J 49(5):231-234.

Lowe BD, Wurzelbacher SJ, Shulman SA, Hudock SD [2001]. Electromyographic and discomfort analysis of confined-space shipyard welding processes. Appl Ergon 32(3):255-269.

Lushniak BD [2001]. Occupational dermatitis causing days away from work in U.S. private industry. Clin Occup Environ Med 1(1):1-12.

Luster MI, Simeonova PP, Gallucci RM, Bruccoleri A, Blazka ME, Yucesoy B [2001]. Role of inflammation in chemical-induced hepatotoxicity. Toxicol Lett 120(1-3):317-321.

Ma Q [2001]. Induction of CYP1A1. The AhR/DRE paradigm: transcription, receptor regulation, and expanding biological roles. Curr Drug Metab 2(2):149-164. 


\section{Journal Articles}

Ma Q, Baldwin KT, Renzelli AJ, McDaniel A, Dong L [2001]. TCDD-inducible poly (ADPribose) polmerase: a novel response to 2,3,7,8-tetrachlorodibenzo- $\rho$-dioxin. Biochem Biophys Res Comm 289(2):499-506.

MacDonald L, Karasek R, Punnett L, Scharf T [2001]. Covariation between workplace physical and psychosocial stressors: evidence and implications for occupational health research and prevention. Ergonomics 44(7):696-718.

MacKinnon PA, Lentz TJ, Rice CH, Lockey JE, Lemasters GK, Gartside PS [2001]. Electron microscopy study of refractory ceramic fibers. Appl Occup Environ Hyg 16(10):944-951.

Maier A, DeBord DG, Savage RE Jr. [2001]. Incorporating biomarkers into the 21 st century risk assessments. Comment Toxicol 7(5-6):519-539.

Mainelis G, Willeke K, Baron PA, Reponen T, Grinshpun SA, Gorny RL, Trakumas S [2001]. Electrical charges on airborne microorganisms. J Aerosol Sci 32(9):1087-1110.

Martinez K, Tubbs RL, Ow P [2001]. Use of local exhaust ventilation to control aerosol exposures resulting from the use of a reciprocating saw during autopsy. Appl Occup Environ Hyg 16(7):709-717.

Matetic RJ, Ingram DK [2001]. Preventing high insurance premiums and on-the-job injuries. Water Well J Aug:10-13.

Matheson JM, Lange RW, Lemus R, Karol MH, Luster MI [2001]. Importance of inflammatory and immune components in a mouse model of airway reactivity to toluene diisocyanate (TDI). Clin Exp Allergy 31:1067-1076.

McCawley MA, Cocco P, Rice CH, Chen JQ, McLaughlin JK, Dosemeci M [2001]. Lung cancer risk, silica exposure, and silicosis in Chinese mines and pottery factories: the modifying role of other workplace lung carcinogens. Am J Ind Med 58:674-682.

McCawley MA, Kent MS, Berakis M [2001]. Ultrafine beryllium number concentration as a possible metric for chronic beryllium disease risk. Appl Occup Environ Hyg 16(5):631-638.

McCullough JE, Dick RB, Rutchik J [2001]. Chronic mercury exposure examined with a computer-based tremor system. J Occup Environ Med 43(3):295-300.

Methner MM, Feng HA, Utterback DF [2001]. Use of historical uranium air sampling data to estimate worker exposure potential to airborne radioactive particulate in a uranium processing facility. Appl Occup Environ Hyg 16(12):1150-1157. 


\section{Journal Articles}

Middendorf P, MacIntosh D, Tow L, Williams P [2001]. Performance of electronic flow rate meters used for calibration of air sampling pumps. Am Ind Hyg Assoc J 62:472-476.

Molinda GM, Mark C, Debasis D [2001]. Using the coal mine roof rating (CMRR) to assess roof stability in U.S. coal mines. J Mines Metals Fuels Aug-Sep:314-321.

Morata TC, Fiorini AC, Fischer FM, Krieg Jr. EF, Gozzoli L, Colacioppo S [2001]. Factors affecting the use of hearing protectors in a population of printing workers. Noise Health $4(13): 25-32$.

Moyer ES, Smith SJ, Wood GO [2001]. Carbon tetrachloride replacement compounds for organic vapor air-purifying respirator cartridge and activated carbon testing - a review. Am Ind Hyg Assoc J 62(4):494-507.

Murono EP, Derk RC, de Leon JH [2001]. Differential effects of octylphenol, 17 $\beta$-estradiol, endosulfan, or bisphenol A on the steroidogenic competence of cultured adult rat Leydig cells. Reprod Toxicol 15:551-560.

Myers JR, Adekoya NA [2001]. Fatal on-farm injuries among youth 16-19 years of age: 1982-1994. J Agric Saf Health 7(2):101-112.

Nelson BK, Snyder DL, Shaw PB [2001]. Developmental toxicity interactions of methanol and radiofrequency radiation or 2-methoxyethanol in rats. Int J Toxicol 20(2):89-100.

Niemeier RW, Obadia I [2001]. International chemical safety cards and global harmonization. Saf Sci 39:107-115.

Nikula KJ, Vallyathan V, Green FHY, Hahn FF [2001]. Influence of exposure concentration or dose on the distribution of particulate material in rat and human lungs. Environ Health Perspect 109(4):311-318.

O’Brien DM, Piacitelli GM, Sieber WK, Hughes RT, Catalano JD [2001]. An evaluation of short-term exposures to metalworking fluids in small machine shops. Am Ind Hyg Assoc J 62(3):342-348.

Okun AH, Lentz TJ, Schulte PA, Stayner LT [2001]. Identifying high-risk small business industries for occupational safety and health interventions. Am J Ind Med 39:301-311.

Organiscak JA, Page SJ [2001]. Airborne dust liberation during coal crushing. Coal Prep $21: 423-453$. 


\section{Journal Articles}

O'Rourke KM, Redlinger TE, Steege AL [2001]. Improving hepatitis B immunization among high-risk adolescents: a low-cost intervention on the Mexico-United States border. Rev Panam Salud Publica. Apr 9(4):228-33.

Ortega HG, Daroowalla F, Petsonk EL, Lewis D, Berardinelli S, Jones W, Kreiss K, Weissman D [2001]. Respiratory symptoms among crab processing workers in Alaska: epidemiological and environmental assessment. Am J Ind Med 39:598-607.

Oyler DC, Mark C, Dolinar DR, Frith RC [2001]. A study of the ground control effects of mining longwall faces into open or backfilled entries. Geotech Geol Eng 19(2):137-168.

Page EH, Pajeau AK, Arnold TC, Fincher AR, Goddard MJ [2001]. Peripheral neuropathy in workers exposed to nitromethane. Am J Ind Med 40:107-113.

Page EH, Trout D [2001]. The role of Stachybotrys mycotoxins in building-related illness. Am Ind Hyg Assoc J 62:644-648.

Page SJ, Organiscak JA [2001]. Suggestions of a cause-and-effect relationship among coal rank, airborne dust, and incidence of workers' pneumoconiosis. Am Ind Hyg Assoc J 61:785-787.

Page SJ, Organiscak JA, Mal T [2001]. The effects of low quartz mass loading and spatial variability on the quartz analysis of surface coal mine dust samples. Appl Occup Environ Hyg 16(9):910-923.

Park Ju-Hyeong, Gold DR, Spiegelman DL, Burge HA, Milton DK [2001]. House dust endotoxin and wheeze in the first year of life. Am J Respir Crit Care Med 163:322-328.

Park Ju-Hyeong, Spiegelman DL, Gold DR, Burge HA, Milton DK [2001]. Predictors of airborne endotoxin in the home. Environ Health Perspect 109(8):859-864.

Park RM [2001]. Medical insurance claims and surveillance for occupational disease: analysis of respiratory, cardiac, and cancer outcomes in auto industry tool grinding operations [2001]. J Occup Environ Med 43(4):335-346.

Park RM [2001]. Mortality at an automotive engine foundry and machining complex. J Occup Environ Med 43(5):483-493.

Peters RH, Fotta B, Mallett LG [2001]. The influence of seam height on lost-time injury and fatality rates at small underground bituminous coal mines. Appl Occup Env Hyg 16(11): 1028-1034. 


\section{Journal Articles}

Petsonk EL, Liss GM [2001]. Workers' compensation claims from latex glove use: a longitudinal analysis of Minnesota data from 1988 to 1997 [Comment on article by Horwitz IB and Arvey RD]. J Occup Environ Med 43(7):590.

Piacitelli GM, Sieber WK, O’Brien DM, Hughes RT, Glaser RA, Catalano JD [2001]. Metalworking fluid exposures in small machine shops: an overview. Am Ind Hyg Assoc J 62(3):356-370.

Poda GI, Landsittel DP, Brumbaugh K, Sharp DS, Frasch F, Demchuk E [2001]. Random sampling or 'random' model in skin flux measurements? [Commentary on "Investigation of the mechanism of flux across human skin in vitro by quantitative structure-permeability relationships"]. Eur J Pharm Sci 14(3):197-200.

Porter DW, Ramsey D, Hubbs AF, Battelli L, Ma J, Barger M, Landsittel D, Robinson VA, McLaurin J, Khan A, Jones W, Teass A, Castranova V [2001]. Time course of pulmonary response of rats to inhalation of crystalline silica: histological results and biochemical indices of damage, lipidosis, and fibrosis. J Environ Pathol Toxicol Oncol 20(Suppl 1):1-14.

Powers JR, Harris JR, Etherton JR, Ronaghi M, Snyder KA, Lutz TJ, Newbraugh BH [2001]. Preventing tractor rollover fatalities: performance of the NIOSH AutoROPS. Inj Prev 7(Suppl I): i54-58.

Powers JR, Harris JR, Etherton JR, Snyder KA, Ronaghi M, Newbraugh BH [2001]. Performance of an automatically deployable ROPS on ASEA test. J Agric Saf Health 7(1):51-61.

Prince M, Ward, E, Ruder A, Salvan A, Roberts D [2001]. Response to: Mortality among rubber chemical manufacturing workers by M.M. Prince et al. [reply to Valentgas et al.'s letter to the editor, Am J Ind Med 37:590-598]. Am J Ind Med 40(4):395-396.

Qiao GL, Riviere JE [2001]. Enhanced systemic tissue distribution after dermal versus intravenous 3,3',4,4'-tetrachlorobiphenyl exposure: limited utility of radiolabel blood area under the curve and excretion data in dermal absorption calculations and tissue exposure assessment. Toxicol Appl Pharmacol 177(1):26-37.

Qian Y, Jiang B-H, Flynn DC, Leonard SS, Wang S, Zhang Z, Ye J, Chen F, Wang L, Shi X [2001]. Cr(VI) increases tyrosine phosphorylation through reactive oxygen species-mediated reactions. Mol Cell Biochem 222(1-2):199-204.

Rao KMK [2001]. MAP kinase activation in macrophages. J Leukoc Biol 69(1):3-10.

Reasor MJ, Antonini JM [2001]. Pulmonary responses to single versus multiple intratracheal instillations of silica in rats. J Toxicol Environ Health A 62(1):9-21. 


\section{Journal Articles}

Redlich CA, Stowe MH, Wisnewski AV, Eisen EA, Karol MH, Lemus R, Holm CT, Chung JS, Sparer J, Liu Y, Woskie SR, Appiah-Pippim J, Gore R, Cullen MR [2001]. Subclinical immunologic and physiologic responses in hexamethylen diisocyanate-exposed auto body shop workers. Am J Ind Med 39:587-597.

Redlinger TE, O'Rourke K, Magana J, Steege A [2001]. Hepatitis B and C among adolescents at an STD clinic on the US-Mexico border. Tex Med 97(10):52-56.

Reh C, Kang D, Herrera-Moreno V [2001]. Mercury exposures during the recycling/reclamation of household-type alkaline batteries. App Occup Environ Hyg 16(11): 993-1005.

Rice FL, Park R, Stayner L, Smith R, Gilbert S, Checkoway H [2001]. Crystalline silica exposure and lung cancer mortality in diatomaceous earth industry workers: a quantitative risk assessment. Occup Environ Med 58(1):31-45.

Richter-Reichhelm HB, Stahlmann R, van Loveren H, Luster MI [2001]. Approaches to risk assessment of immunotoxic effects of chemicals. Toxicology 161:213-228.

Rider JP, Colinet JF, Listak JM, Chekan GJ [2001]. Evaluating longwall dust sources and controls. World Coal 10(10):71-76.

Rojas M, Drake PL, Roberts SM [2001]. Assessing mercury health effects in gold workers near El Callao, Venezuela. J Occup and Environ Med 43(2):158-165.

Ruder A, Ward E, Brown D [2001]. Mortality in dry-cleaning workers: an update. Am J Ind Med 39:121-132.

Rudolph L. Deitchman S, Dervin K [2001]. Integrating occupational health services and occupational prevention services. Am J Ind Med 40(3):307-318.

Rudzinski WE, Yin J, England E, Carlton G, Key-Schwartz RJ, Lesage J [2001]. A comparison of solid sampler methods for the determination of mexamethylene-based isocyanates in spray-painting operations. Am Ind Hyg Assoc J 62(2):246-250.

Ruff TM [2001]. Application of radar to detect pedestrian workers near mining equipment. Appl Occup Environ Hyg 16(8):798-808.

Ruff TM [2001]. Monitoring blind spots: a major concern for haul trucks. Eng Min J 202(12):17-26.

Ruff TM, Hession-Kunz D [2001]. Application of radio-frequency identification systems to collision avoidance in metal/nonmetal mines. IEEE Trans Ind Appl 37(1):112-116. 


\section{Journal Articles}

Sacks HK, Cawley JC, Homce GTR, Yenchek MR [2001]. Feasibility study to reduce injuries and fatalities caused by contact of cranes, drill rigs, and haul trucks with high-tension lines. IEEE Trans Ind Appl 37(3):914-919.

Sanderson WT, Petersen M, Ward E [2001]. Estimating historical exposures of workers in a beryllium manufacturing plant. Am J Ind Med 39:145-157.

Sanderson WT, Ward E, Steenland K [2001]. Re: Response to criticisms of "Lung cancer casecontrol study of beryllium workers.” Am J Ind Med 40:286-288.

Sanderson WT, Ward E, Steenland K, Petersen M [2001]. Lung cancer case-control study of beryllium workers. Am J Ind Med 39:133-144.

Sargent LM, Nelson MA, Lowry DT, Senft JR, Jefferson AM, Ariza ME, Reynolds SH [2001]. Detection of three novel translocation and specific common chromosomal break sites in malignant melanoma by spectral karyotyping. Genes Chromosomes Cancer 32(1):18-25.

Schachter EN, Zuskin E, Rienzi N, Goswami S, Castranova V, Whitmer M, Siegel P [2001]. Pharmacologic properties of brewery dust extracts in vitro. Chest 119(6):1870-1877.

Scharf T, Vaught C, Kidd P, Steiner LJ, Kowalski KM, Wiehagen WJ, Rethi LL, Cole HP [2001]. Toward a typology of dynamic and hazardous work environments. Hum Ecol Risk Assess 7(7):1827-1841.

Scheerer A [2001]. Occupational burn surveillance in Kentucky. Kentucky Epidemiological Notes \& Reports 36(5):1-3.

Schmidt GR, Yemm RS, Childs KD, O'Callaghan JP, Hossner KL [2001]. The detection of central nervous system tissue on beef carcasses and in comminuted beef. J Food Protection 64(12):2047-2052.

Schnakenberg GH Jr. [2001]. Estimate of technically feasible DPM levels for underground metal and nonmetal mines. Min Eng 53(9):45-51.

Schnorr TM, Lawson CC, Whelan EA, Dankovic DA, Deddens JA, Piacitelli LA, Reefhuis J, Sweeney MH, Connally LB, Fingerhut MA [2001]. Spontaneous abortion, sex ratio and paternal occupational exposure to 2,3,7,8-tetrachlorodibenzo-p-dioxin. Environ Health Perspect 109:1127-1132.

Schubauer-Berigan MK, Wenzl TB [2001]. Leukemia mortality among radiation-exposed workers. Occup Med: State-of-the-Art Rev 16(2):271-287. 


\section{Journal Articles}

Shi X, Ding M, Chen F, Wang L, Rojanasakul Y, Vallyathan V, Castranova V [2001]. Reactive oxygen species and molecular mechanism of silica-induced lung injury. J Environ Pathol Toxicol Oncol 20(Suppl 1):85-93.

Shvedova AA, Kisin E, Kisin J, Castranova V, Kommineni C [2001]. Elevated oxidative stress in skin of B6C3F1 mice affects dermal exposure to metal-working fluid. Toxicol Ind Health 16(7-8):267-276.

Shvedova AA, Tyurina YY, Tyurin VA, Kikuchi Y, Kagan VE, Quinn PJ [2001]. Quantitative analysis of phospholipid peroxidation and antioxidant protection in live human epidermal keratinocytes. Biosci Rep 21(1):33-43.

Sieber WK, Green TA, Haugh GS, Kresnow MJ, Luman ET, Wilson HG [2001]. Symposium on emerging statistical issues in public health for the 21st Century. Stat Med 20:9-10.

Simeonov P, Hsiao H [2001]. Height, surface firmness and visual reference effects on balance control. Inj Prev 7(Suppl I):i50-53.

Simeonova PP, Wang S, Kashon ML, Kommineni C, Crecelius E, Luster MI [2001].

Quantitative relationship between arsenic exposure and AP-1 activity in mouse urinary bladder epithelium. Toxicol Sci 60(2):279-284.

Song R, Kennedy ER, Bartley DL [2001]. Uniformity test of bias when the reference value contains experiment error. Analyt Chem 73(2):310-314.

Song R, Schlecht PC, Ashley KE [2001]. Field screening test methods: performance criteria and performance characteristics. J Hazard Mater 83(1-2):29-39.

Steenland K, Calvert G, Michalek J, Ketchum N [2001]. Dioxin and diabetes mellitus: an analysis of the combined NIOSH and ranch hand data. Occup Environ Med 58:641-648.

Steenland K, Deddens J, Piacitelli L [2001]. Risk assessment for 2,3,7,8-p-dioxin (TCDD) based on an epidemiologic study. Am J Epidemiol 154:451-458.

Steenland K, Dick R, Fine L [2001]. Agreement between clinical examination and quantitative tests of neurologic function. Am J Ind Med 39:361-368.

Steenland K, Mannetje A, Boffetta P, Stayner L, Attfield MD, Chen J, Dosemeci M, DeKlerk N, Hnizdo E, Koskela R, Checkoway H [2001]. Pooled exposure-response analyses and risk assessment for lung cancer in 10 cohorts of silica-exposed workers: an IARC multicentre study. Cancer Causes Control 12:773-784. 


\section{Journal Articles}

Steenland K, Sanderson W [2001]. Lung cancer among industrial sand workers exposed to crystalline silica. Am J Epidemiol 153:695-703.

Steenland K, Sanderson W, Calvert G [2001]. Kidney disease and arthritis among workers exposed to silica. Epidemiology 12:405-412.

Stern F, Lehman E, Ruder A [2001]. Mortality among unionized construction plasterers and cement masons. Am J Ind Med 39:373-388.

Stout N [2001]. The relevance of occupational injury research. Inj Prev 7(Suppl I):i1-2.

Stout N, Linn H [2001]. From strategy to reality: 25 years of planning and progress in occupational injury research. Inj Prev 7(Suppl I):i11-14.

Sugawara T, Gallucci RM, Simeonova PP, Luster MI [2001]. Regulation and role of interleukin 6 in wounded human epithelial keratinocytes. Cytokine 15(6):328-336.

Sutovsky P, Moreno R, Ramalho-Santos J, Dominko T, Simerly C, Schatten G [2001]. Ubiquitin-dependent epidermal mechanism for the recognition and elimination of defective spermatozoa in mammals. J Cell Sci 114:1665-1675.

Sutovsky P, Terada Y, Schatten G [2001]. Ubiquitin-based sperm assay for the diagnosis of male factor infertility. Hum Reprod 16:250-258.

Swaroop N, Chen F, Wang L, Dokka S, Toledo D, Rojanasakul Y [2001]. Inhibition of nuclear transcription factor- $\kappa \mathrm{B}$ by specific IкB kinase peptide inhibitor. Pharm Res 18(11):1631-1633.

Taylor L, Jones RL, Kwan L, Deddens JA, Ashley KE, Sanderson WT [2001]. Evaluation of a portable blood lead analyzer with occupationally exposed populations. Am J Ind Med 40(4):354-362.

Tepper AL, Mueller C, Singal M, Sagar K [2001]. Blood pressure, left ventricular mass, and lead exposure in battery manufacturing workers. Am J Ind Med 40(1):63-72.

Thomas TK, Lincoln JM, Husberg BJ, Conway CA [2001]. Is it safe on deck? Fatal and nonfatal workplace injuries among Alaskan commercial fishermen. Am J Ind Med 40:693-702.

Tickner J, Armstrong T, Bloom T [2001]. Workshop on harmonization of serving future needs with occupational exposure databases-inhalation modeling, session IIIA. Appl Occup Environ Hyg 16(2):309-314. 


\section{Journal Articles}

Tiffany-Castiglioni E, Guerri C, Aschner M, Matsushima GK, O’Callaghan JP, Streit WJ [2001]. Roles of glia in developmental neurotoxicity: session VI summary and research needs. Neurotoxicology 22(5):567-573.

Topmiller JL, Flesch JP [2001]. Hazard controls: control of wood dust from automated routers. Appl Occup Environ Hyg 16(10):940.

Topmiller JL, Flesch JP [2001]. Hazard controls: control of wood dust from large diameter disc sanders. Appl Occup Environ Hyg 16(11):1022.

Topmiller JL, Flesch JP [2001]. Hazard controls: control of wood dust from random orbital hand sanders. Appl Occup Environ Hyg 16(12):1091.

Topmiller JL, Flesch JP [2001]. Hazard controls: control of wood dust from shapers. Appl Occup Environ Hyg 16(9):849.

Toraason MA, Hayden II CS, Marlow DA, Rinehart R, Mathias PI, Werren DM, DeBord DG, Reid TM [2001]. DNA strand breaks, oxidative damage, and 1-OH pyrene in roofers with coal-tar pitch dust and/or asphalt fume exposure. Int Arch Occup Environ Health 74(6):396-404.

Trinkoff AM, Storr CL, Lipscomb JA [2001]. Physically demanding work and inadequate sleep, pain medication use, and absenteeism in registered nurses. J Occup Environ Med 43(4):355-363.

Trout D, Bernstein J, Martinez K, Biagini RE, Wallingford K [2001]. Bioaerosol lung damage in a worker with repeated exposure to fungi in a water-damaged building. Environ Health Perspect 109:(6):641-644.

Trutt FC, Sottile J, Kohler JL [2001]. Detection of a-c machine winding deterioration using electrically excited vibrations. IEEE Trans Ind Appl 37(1):10-14.

Trutt FC, Sottile J, Kohler JL [2001]. Detection of electrical winding deterioration in induction motors. Electric Power Components \& Systems 29:1025-1033.

Tubbs RL [2001]. Excessive noise levels in laboratory work spaces produced by the heating, ventilating, and air conditioning systems. Appl Occup Environ Hyg 16:(5):497-501.

Tucker SP [2001]. Determination of capsaicin and dihydrocapsaicin in air in a pickle and pepper processing plant. Am Ind Hyg Assoc J 62(1):45-48.

Tucker SP, Reynolds JM, Wickman DC, Hines CJ, Perkins JB [2001]. Development of sampling and analytical methods for concerted determination of commonly used chloroacetanilide, chlorotriazine, and 2,4-D herbicides in hand-wash, dermal-patch, and air samples. Appl Occup Environ Hyg 16(6):698-707. 


\section{Journal Articles}

Van Loveren H, Vos JG, Germolec D, Simeonova PP, Eijkemanns G, McMichael AJ [2001]. Epidemiologic associations between occupational and environmental exposures and autoimmune disease: report of a meeting to explore current evidence and identify research needs. Int J Hyg Environ Health 203(5-6):483-495.

Vineis P, Schulte P, McMichael AJ [2001]. Misconceptions about the use of genetic tests in populations. Lancet 357:709-712.

Vineis P, Schulte P, McMichael AJ [2001]. Relevance of high and low penetrance [correspondence]. Lancet 258:331-332.

Vo E [2001]. A new technique to determine organic and inorganic acid contamination. Analyst 126:1-5.

Vo E, Berardinelli S, Boeniger M [2001]. Analysis of some commonly used solvents on 3M Empore filters using solvent desorption and gas chromatography. Appl Occup Environ Hyg 16(7):1-7.

Vo E, Berardinelli S, Boeniger M [2001]. The use of 3M porous polymer extraction discs in assessing protective clothing chemical permeation. Appl Occup Environ Hyg 16(7):729-735.

Wagner J, Leith D [2001]. Field tests of a passive aerosol sampler. J Aerosol Sci 32:33-48.

Wagner J, Leith D [2001]. Passive aerosol sampler. Part I: Principle of operation. Aerosol Sci Technol 34:186-192.

Wagner J, Leith D [2001]. Passive aerosol sampler. Part II: Wind tunnel experiments. Aerosol Sci Technol 34:193-201.

Wallace ME, Landon D, Song R, Echt AS [2001]. Case studies: a field evaluation of the effect of pulsed arc welding technique on reducing worker exposures. Appl Occup Environ Hyg 16(2): 93-97.

Wallace ME, Shulman SA, Sheehy JW [2001]. Case studies: comparing exposure levels by type of welding operation and evaluating the effectiveness of fume extraction guns. Appl Occup Environ Hyg 16(8):771-779.

Wang J, Lewis DM, Castranova V, Frazer DG, Goldsmith T, Tomblyn S, Simpson J, Stone S, Afshari A, Siegel PD [2001]. Characterization of asphalt fume composition under simulated road paving conditions by GC/MS and microflow LC/quadrupole time-of-flight MS. Analyt Chem 73(15):3691-3700. 


\section{Journal Articles}

Wang RC, McKewan WM [2001]. A model for the structure of round-strand wire ropes. Organisation Internationale pour l'Etude de l'Endurance des Cables (OIPEEC) (International Organisation for the Study of the Endurance of Ropes), Bulletin 81. Reading, U.K.: Reading Rope Research, Department of Engineering, University of Reading, pp.15-42.

Wang S, Shi X [2001]. Mechanisms of Cr(VI)-induced p53 activation: the role of phosphorylation, mdm2 and ERK. Carcinogenesis 22(5):757-762.

Wang S, Shi X [2001]. Molecular mechanisms of metal toxicity and carcinogenesis. Mol Cell Biochem 222(1-2):3-9.

Ward E, Boffetta P, Andersen A, Colin D, Comba P, Deddens J, De Santis M, Engholm G, Hagmar L, Langard S, Lundberg I, McElvenny D, Pirastu R, Sali D, Simonato L [2001]. Update of the follow-up of mortality and cancer incidence among European workers employed in the vinyl chloride industry. Epidemiology 12(6):710-718.

Washenitz F II, Stoltzfus J, Newton B, Kubinski L [2001]. Fire incidents involving regulators used in portable oxygen systems. Inj Prev 7(Suppl I):i34-37.

Wassell JT, Bailer AJ [2001]. Occupational injury risk assessment: perspective and introduction to the second special issue. Hum Ecol Risk Assess 7(7):1775-1776.

Wassell JT, Gardner LI, Landsittel DP [2001]. Does back belt use prevent on-the-job back pain and injury? National Safety Council Injury Insights June/July:1-2.

Weissman DN, Hubbs AF, Huang S-H, Stanley CF, Rojanasakul Y, Ma JKH [2001]. IgG subclass responses in experimental silicosis. J Environ Pathol Toxicol Oncol 20(Suppl 1): $67-74$.

Williamson AM, Feyer AM, Stout N, Driscoll T, Usher H [2001]. Use of narrative analysis for comparisons of the causes of fatal accidents in three countries: New Zealand, Australia, and the United States. Inj Prev 7(Suppl I):i115-120.

Wisnewski A, Redlich CA [2001]. Recent developments in diisocyanate asthma. Current Opin Allergy Immunol 1:169-175

Wisnewski AV, Cain H, Magoski N, Wang H, Holm CT, Redlich CA [2001]. Human gamma/delta T-cell lines derived from airway biopsies. Am J Respir Cell Mol Biol 24:332-8.

Woodfork KA, Schuller KC, Huffman LJ [2001]. Cytokine and nitric oxide release by J774A.1 macrophages is not regulated by estradiol. Life Sci 69(19):2287-2294. 


\section{Journal Articles}

Wu Z-X, Maize DF Jr., Satterfield BE, Frazer DG, Fedan JS, Dey RD [2001]. Role of intrinsic airway neurons in ozone-induced airway hyperresponsiveness in ferret trachea. J Appl Physiol 91(1):371-378.

Yang HM, Antonini JM, Barger MW, Butterworth L, Roberts JR, Ma JKH, Castranova V, Ma JYC [2001]. Diesel exhaust particles suppress macrophage function and slow the pulmonary clearance of listeria monocytogenes in rats. Environ Health Perspect 109(5):515-521.

Ye J, Shi X [2001]. Gene expression profile in response to chromium-induced cell stress in A549 cells. Mol Cell Biochem 222(1-2):189-197.

Ye J, Zeidler PC, Young S, Martinez AB, Robinson VA, Jones W, Baron PA, Shi X, Castranova V [2001]. Activation of mitogen-activated protein kinase p38 and extracellular signal-regulated kinase is involved in glass fiber-induced tumor necrosis factor-alpha production in macrophages. J Biol Chem 276(7):5360-5367.

Yeskey K, Calvert GM [2001]. Nosocomial poisoning associated with emergency department treatment of organophosphate toxicity-Georgia 2000. J Am Med Assoc 285:527-528.

Yong LC, Schulte PA, Wiencke J, Boeniger MF, Connally LB, Walker JT, Whelan EA, Ward EM [2001]. Hemoglobin adducts and sister chromatid exchanges in hospital workers exposed to ethylene oxide: effects of Glutathione S-Transferase T1 and M1 genotypes. Cancer Epidemiol Biomarkers Prev 10:538-550.

Young S-H, Robinson VA, Barger M, Porter DW, Frazer, DG, Castranova V [2001]. Acute inflammation and recovery in rats after intratracheal instillation of a $1 \rightarrow 3-\beta$-glucan (zymosan A). J Toxicol Environ Health A 64(4):311-325.

Young S-H, Ye J, Frazer DG, Shi X, Castranova V [2001]. Molecular mechanism of tumor necrosis factor- $\alpha$ production in $1 \rightarrow 3$ - $\beta$-glucan (zymosan)-activated macrophages. J Biol Chem 276(23):20781-20787.

Yucesoy B, Vallyathan V, Landsittel DP, Sharp DS, Matheson J, Burleson F, Luster MI [2001]. Polymorphisms of the IL-1 gene complex in coal miners with silicosis. Am J Ind Med 39(3):286-291.

Yucesoy B, Vallyathan V, Landsittel DP, Sharp DS, Weston A, Burleson GR, Simeonova P, McKinstry M, Luster MI [2001]. Association of tumor necrosis factor- $\alpha$ and interleukin-1 gene polymorphisms with silicosis. Toxicol Appl Pharmacol 172(1):75-82.

Zhang Z, Huang C, Li J, Leonard SS, Lanciotti R, Butterworth L, Shi X [2001]. Vanadateinduced cell growth regulation and the role of reactive oxygen species. Arch Biochem Biophys 392(2):311-320. 


\section{Journal Articles}

Zhang Z, Leonard SS, Wang S, Vallyathan V, Castranova V, Shi X [2001]. Cr(VI) induces cell growth arrest through hydrogen peroxide-mediated reactions. Mol Cell Biochem 222(1-2): $77-83$.

Zhang X, Ye J, Wang L, Manosroi J, Shi X, Rojanasakul Y [2001]. Rapid and sensitive assay of tumor necrosis factor- $\alpha$ gene transcription. Pharm Res 18(3):408-411.

Zhong B-Z, Depree GJ, Siegel PD [2001]. Differentiation of the mechanism of micronuclei induced by cysteine and glutathione conjugates of methylenedi-p-phenyl diisocyanate from that of 4,4"-methylenedianiline. Mutat Res 497(1-2):29-37.

Zhuang Z, Hearl FJ, Odencrantz J, Chen W, Chen BT, Chen JQ, McCawley MA, Gao P, Solderholm SC [2001]. Estimating historical respirable crystalline silica exposures for Chinese pottery workers and iron/copper, tin and tungsten miners. Ann Occup Hyg 45(8):631-642.

Zimmer AT, Biswas P [2001]. Characterization of the aerosols resulting from arc welding processes. J Aerosol Sci 32(8):993-1008. 


\section{BOOK CHAPTERS/PROCEEDINGS/ABSTRACTS/ TECHNICAL PAPERS}

Al-Humadi NH, Siegel PD, Lewis DM, Barger M, Ma JYC, Weissman DN, Ma JKH [2001]. Effect of exposure to diesel exhaust particles (DEP) on pulmonary allergic sensitization [Abstract]. Toxicol 164(1-3):119-120.

Al-Humadi NH, Siegel PD, Lewis DM, Ma JY, Ma JK [2001]. Diesel exhaust particulate (DEP) affected thiol levels in both alveolar macrophages (AM) and lymph node cells (LNC) [Abstract]. The Toxicologist 60(1):167.

Ambrose DH [2001]. Random motion capture model for studying events between a machine and its operator. In: Proceedings of the Advanced Simulation Technologies Conference. San Diego, CA: Society for Computer Simulation International, pp.127-134.

Antonini JM, Ebeling AR, Roberts JR [2001]. Highly-soluble stainless steel welding fume slows the pulmonary clearance of a bacterial pathogen and severely damages the lungs after infection [Abstract]. The Toxicologist 60(1):424.

Attfield MD, Costello J [2001]. Use of an existing database to evaluate lung cancer risk and silica exposure in Vermont granite workers [Abstract]. In: Hagsberg M, Knave B, Lillienberg L, Westberg H, eds. X2001 Exposure Assessment in Epidemiology and Practice Conference (Göteborg, Sweden), pp.341-343.

Backus AS, Brochu PJ, Lincoln JM, Bensyl DM, Ciampa JR, Smith TJ [2001]. Understanding and preventing lobsterman entanglement: a preliminary study. In: Proceedings of the Marine Safety Council, Vol. 58 (2):50-53.

Baldwin K, Ma Q [2001]. Transcriptional regulation of TIGI, a novel TCDD-inducible gene, by the aryl hydrocarbon receptor [Abstract]. The Toxicologist 60(1):123.

Bang KM [2001]. Prevalence of asthma among adults by occupation and industry in the United States [Abstract]. Am J Epidemiology 153(11):S137.

Barczak TM [2001]. Design considerations for the next generation of longwall shields. In: Proceedings of Longwall USA International Exhibition \& Conference. Overland Park, KS: Intertec Publishing Corp., pp.17-38. 


\section{Book Chapters/Proceedings/Abstracts/Technical Papers}

Barczak TM [2001]. Mistakes, misconceptions, and key points regarding secondary roof support systems. In: Peng SS, Mark C, Khair AW, eds. Proceedings of the 20th International Conference on Ground Control in Mining. Morgantown, WV: West Virginia University, pp.347-356.

Barczak TM [2001]. Updating the NIOSH Support Technology Optimization Program (STOP) with new support technologies and additional design features. In: Peng SS, Mark C, Khair AW, eds. Proceedings of the 20th International Conference on Ground Control in Mining. Morgantown, WV: West Virginia University, pp.337-346.

Baron PA [2001]. Evaluation of alternate cyclones for respirable dust sampling. Cincinnati, OH: U.S. Department of Health and Human Services, Public Health Service, Centers for Disease Control and Prevention, National Institute for Occupational Safety and Health. Technical report submitted to OSHA.

Baron PA, Heitbrink WA [2001]. Chapter 7: An approach to performing aerosol measurements. In: Baron PA, Willeke K, eds. Aerosol measurement: principles, techniques, and applications. 2nd ed. New York, NY: John Wiley and Sons, Inc., pp.117-139.

Baron PA, Mazumder MK, Cheng YS [2001]. Chapter 17: Direct-reading techniques using particle motion and optical detection. In: Baron PA, Willeke K, eds. Aerosol measurement: principles, techniques, and applications. 2nd ed. New York, NY: John Wiley and Sons, Inc., pp. 495-535.

Baron PA, Sorensen CM, Brockmann JE [2001]. Chapter 23: Nonspherical particle measurement: shape factors, fractals, and fibers. In: Baron PA, Willeke K, eds. Aerosol measurement: principles, techniques, and applications. 2nd ed. New York, NY: John Wiley and Sons, Inc., pp.705-749.

Baron PA, Willeke K, eds. [2001]. Aerosol measurement: principles, techniques, and applications. 2nd ed. New York, NY: John Wiley and Sons, Inc.

Baron PA, Willeke K [2001]. Chapter 2: Bridging science and application in aerosol measurement: accessing available tools. In: Baron PA, Willeke K, eds. Aerosol measurement: principles, techniques, and applications. 2nd ed. New York, NY: John Wiley and Sons, Inc., pp.31-43.

Baron PA, Willeke K [2001]. Chapter 3: Aerosol fundamentals. In: Baron PA, Willeke K, eds. Aerosol measurement: principles, techniques, and applications. 2nd ed. New York, NY: John Wiley and Sons, Inc., pp.45-60.

Baron PA, Willeke K [2001]. Chapter 4: Gas and particle motion. In: Baron PA, Willeke K, eds. Aerosol measurement: principles, techniques, and applications. 2nd ed. New York, NY: John Wiley and Sons, Inc., pp.61-82. 


\section{Book Chapters/Proceedings/Abstracts/Technical Papers}

Barrelli LA, Hubbs AF, Ma JY, Kashon ML, Castranova V [2001]. Quantifying cellular expression of cytochrome P450 1A1 (CYP1A1) in the pulmonary alveolus: a comparison of indirect enzymatic immunohistochemistry (IH) and indirect immunofluorescence (IF) [Abstract]. The Toxicologist 60(1):403.

Bartels JR, Ambrose DH, Wang RC [2001]. Verification and validation of roof bolter simulation models for studying events between a machine and its operator. Warrendale, PA: Society of Automotive Engineers, Inc., technical paper 2001-01-2088.

Bauer ER, Podobinski DJ, Reeves ER [2001]. Noise exposure in longwall mining and engineering controls research. In: Proceedings of Longwall USA International Exhibition \& Conference. Overland Park, KS: Intertec Publishing Corp., pp.51-69.

Benkovic SA, O’Callaghan JP, Miller DB [2001]. Supraphysiological levels of corticosterone and kainic acid: failure to find increased hippocampal neurotoxicity in the kainate resistant C57BL/6J mouse [Abstract]. The Toxicologist 60(1):372.

Beus MJ, Pariseau WG, Stewart BM, Iverson SR [2001]. Chapter 71: Design of ore passes. In: Hustrulid H, Bullock R, eds. Underground mining methods: Engineering Fundamentals and International Case Studies. Littleton, CO: Society for Mining, Metallurgy, and Exploration, pp.627-634.

Brady TM, Johnson JC, Laurenti MA, Pariseau WG, Stahl S [2001]. Mining the remaining portion of the Ross shaft pillar. In: Elsworth D, Tinnucci JP, Heasley KA, eds. Rock Mechanics in the Public Interest. In: Proceedings of the 38th U.S. Rock Mechanics Symposium, DC Rocks, Vol. 1 (Washington, DC, July 7-10, 2001). Rotterdam: Balkema, pp.395-399.

Bugarski A, Gautam M [2001]. Size distribution and deposition in human respiratory tract: particle mass and number: In: Proceedings 4th International ETH-Conference on Nanoparticle Measurement (Bern, Switzerland, August 7-9, 2000), pp.1-12.

Butler MA, Flugel CA, Krieg Jr. EF, Snawder JE, Kesner JS [2001]. Gene environment interactions and exposure to JP-8 jet fuel. In: JP8: Final Risk Assessment. Lubbock, TX: The Institute of Environmental and Human Health, pp.76-80.

Butler MA, Ruder AM, Waters MA, Daly AK, Schulte PA [2001]. Successes in DNA preparation for identification of biomarkers of exposure, effects of exposure and susceptibility in cancer cases and controls in rural areas. In: Proceedings of 92nd Annual Meeting of the American Association for Cancer Research. Vol. 42, No. 4759, pp. 885-886.

Byars JD, Mucho TP, Zick RL [2001]. Discharge water handling and treatment: problems and solutions at a large Pittsburgh seam coal mine. SME preprint 01-162. Littleton, CO: Society for Mining, Metallurgy, and Exploration, Inc. 


\section{Book Chapters/Proceedings/Abstracts/Technical Papers}

Calvert GM, Sanderson WT, Barnett M, Blondell JM, Mehler LN [2001]. Surveillance of pesticide-related illness and injury in humans. In: Krieger R, ed. Handbook of pesticide toxicology. 2nd ed. San Diego: Academic Press, pp.603-641.

Cantrell BK, Volkwein JC [2001]. Mine aerosol measurement. In: Baron PA, Klaus W, eds. Aerosol measurement: principles, techniques, and applications. 2nd ed. New York, NY: WileyInterScience, Inc., pp.801-820.

Carreon T, Ruder AM, Schulte PA, Hayes RB, Rothman N, Lemasters GK, Grant DJ, Boissy R, Bell DA, Kadlubar FF, Hemstreet GP, Yin S, Li G, Feng P [2001]. Effect of metabolic polymorphisms on benzidine-induced bladder cancer in Chinese workers: a nested case-control study [Abstract]. Am J Epidemiol 153:5199.

Cawley JC [2001]. Electrical accidents in the mining industry, 1990-1999. In: Conference Record of the 2001 IEEE Industry Applications Conference, 36th IAS Annual Meeting, Chicago, IL.

Cecala AB, Organiscak JA, Page SJ, Heitbrink WA, Thimons ED [2001]. Current NIOSH dust control research for noncoal surface mines. In: Proceedings of the National Stone, Sand \& Gravel Association Environment, Safety \& Health Forum. Arlington, VA: National Stone, Sand \& Gravel Association, pp.87-100.

Chekan GJ, Listak JM, Colinet JF [2001]. Laboratory testing to quantify dust entrainment during shield advance. In: Proceedings of the Seventh International Mine Ventilation Congress (Krakow, Poland), pp.291-298.

Chiou S, Pan CS, Zwiener JZ, Long D, Cantis D [2001]. Assessment of fall potential associated with drywall lifting. In: Bittner A, ed. Proceedings of the 15th Annual Conference of the International Society for Occupational Ergonomics and Safety. Vol. 4. Fairfax, VA: Advances in Occupational Ergonomics and Safety, pp.55-61.

Conti RS [2001]. Emerging technologies: aiding responders in mine emergences and during the escape from smoke-filled passageways. In: Proceedings of the Northwest Mining Association 107th Annual Meeting (Spokane, WA), pp.1-14.

Cornelius KM, Turin FC [2001]. Ergonomics considerations for reducing cumulative trauma exposure in underground mining. In: Karwowski W, ed. International encyclopedia of ergonomics and human factors. Vol. III. London, U.K.: Taylor \& Francis, Inc., pp.1497-1500.

Cornelius KM, Turin FC [2001]. Recommendations for reducing mine worker cumulative trauma exposure. In: Proceedings of the IIE 10th Annual Research Conference. Norcross, GA: Institute of Industrial Engineers. CD-ROM. 


\section{Book Chapters/Proceedings/Abstracts/Technical Papers}

Cornelius KM, Turin FC, Wiehagen WJ, Gallagher S [2001]. An approach to identify jobs for ergonomic analysis. In: Proceedings of the IIE 10th Annual Research Conference. Norcross, GA: Institute of Industrial Engineers. CD-ROM.

Courtney TK, Sorock GS, Manning DP, Collins JW, Holbein-Jenny MA [2001]. Occupational slip, trip, and fall-related injuries-can the contribution of slipperiness be isolated? Ergonomics 44(13):1118-1137.

Cutlip RG, Wirth O, Miller R, Geronilla K, Mowrey K [2001]. An in vivo animal model for the investigation of acute and chronic skeletal muscle injury. In: Bittner AC Jr., Champney PC, Morrissey SJ, eds. Proceedings of the 15th Annual Conference of the International Society for Occupational Ergonomics and Safety, Advances in occupational ergonomics and safety, Vol. 4: Amsterdam, the Netherlands, pp.394-401.

Cutlip RG, Wu J-Z [2001]. Effects of oscillatory contractions on the mechanical damage of skeletal muscle [Abstract]. In: Muller R, Gerer H, Stacoff A, eds. Proceedings of the International Society of Biomechanics 18th Congress, Zurich, Switzerland:P630.

Cutlip RG, Wu J-Z [2001]. Effects of velocity during oscillatory contractions on the mechanical damage of skeletal muscle [Abstract]. In: Muller R, Gerber H, Stacoff A, eds. Proceedings of the International Society of Biomechanics 18th Congress, Zurich, Switzerland:P631.

Davis RR [2001]. Chapter 31: noise-induced hearing loss. In: Willott JF, ed. Handbook of mouse auditory research: from behavior to molecular biology. Boca Raton, FL: CRC Press, pp.477-488.

Dean JH, House RV, Luster MI [2001]. Immunotoxicology: effects of, and response to, drugs and chemicals. In: Hayes AW, ed. Principles and methods of toxicology. 4th ed. Philadelphia: Taylor \& Francis, pp.1415-1450.

Demchuk E, Singh H, Hnizdo V, Mardia KV, Sharp DS [2001]. Statistics and molecular structure of biological macromolecules. In: Mardia KV, Aykroyd RG, eds. Proceedings in Functional and Spatial Data Analysis incorporating the 20th Leeds Annual Statistical Research Workshop, Leeds, U.K., pp.9-14.

Depree GJ, Siegel PD [2001]. A chromatographic method for determination of 3-amino-5mercapto-1,2,4-triazole in biological fluids [Abstract]. The Toxicologist 60(1):53.

Diamond WP, Schatzel SJ, Garcia F, Ulery JP [2001]. The modified direct method: a solution for obtaining accurate coal desorption measurements. In: Proceedings of the International Coalbed Methane Symposium. Tuscaloosa, AL: University of Alabama, pp.331-342.

Dolinar DR, Mark C, Molinda GM [2001]. Design of primary roof support systems in U.S. coal mines based on the analysis of roof fall rates. In: Proceedings of the Fourth International Symposium on Roof Bolting in Mining (Aachen, Germany), pp.235-252. 


\section{Book Chapters/Proceedings/Abstracts/Technical Papers}

Dolinar DR, Mucho TP, Oyler DC, Pablic J [2001]. “Advance and relieve” mining: a method to mitigate the effects of high horizontal stress on the mine roof. SME preprint 01-113. Littleton, CO: Society for Mining, Metallurgy, and Exploration, Inc.

Dong RG, Bader J, Welcome D, Rakheja S, Schopper AW [2001]. An accurate method for measuring the exposure duration of hand-transmitted vibration. In: Cox LN, Arrowsmith CI, Holmes SR, eds. Proceedings of the 36th UK Group Conference on Human Response to Vibration, Farnborough, U.K., pp.416-424.

Dong RG, Rakheja S, Smutz PW, Schopper AW, Caporali SA, Stone S, Bader J [2001]. Dynamic characteristics of the instrumented handle and adapter recommended in the ISO 10819, 1996 [Abstract]. In: Abstracts of the 9th International Conference on Hand-Arm Vibration, Nancy, France.

Dong RG, Smutz WP, Rakheja S, Schopper AW, Welcome D, Wu JZ [2001]. Alternate methods for assessment of vibration attenuation performance of gloves [Abstract]. In: Abstracts of the 9th International Conference on Hand-Arm Vibration, Nancy, France.

Du Plessis JJL, Weiss ES, Cashdollar KL [2001]. Evaluation of the bagged stone dust barrier effectiveness in a bord and pillar mine. In: Wasilewski S, ed. Proceedings of the Seventh International Mine Ventilation Congress (Krakow, Poland), chapter 81, pp.573-580.

Edwards JC, Franks RA, Friel GF, Lazzara CP, Opferman JJ [2001]. Underground fire detection and nuisance alarm discrimination. Coal Age 106(7):70-72.

Edwards JC, Franks RA, Friel GF, Lazzara CP, Opferman JJ [2001]. Discriminatory mine fire source detection. In: Wasilewski S, ed. Proceedings of the Seventh International Mine Ventilation Congress (Krakow, Poland), chapter 91, pp.649-655.

Edwards JC, Friel GF, Franks RA, Lazzara CP, Opferman JJ [2001]. Mine fire source discrimination using fire sensors and neural network analysis. In: Proceedings of the 29th International Conference of Safety in Mines Research Institutes. Vol. 2. Katowice, Poland: Central Mining Institute, pp.7-15.

El-Fawal HA, O'Callaghan JP [2001]. Neurotoxicity of trimethyl tin (TMT) assessed using autoantibodies to neurotypic and gliotypic proteins [Abstract]. The Toxicologist 60(1):188.

Ellenberger JL, Heasley KA, Swanson PL, Mercier J [2001]. Three-dimensional microseismic monitoring of a Utah longwall. In: Elsworth D, Tinucci JP, Heasley KA, eds. Rock mechanics in the national interest. Vol. II. Lisse, Netherlands: Swets \& Zeitlinger, pp.1321-1326.

Estill CF, MacDonald LA [2001]. Ergonomics of household appliance assembly. In: Proceedings of the 2001 Appliance Manufacturer Conference, Cincinnati, OH: pp.317-330. 


\section{Book Chapters/Proceedings/Abstracts/Technical Papers}

Etherton J, McKenzie E [2001]. The machine operator's jammed-feedstock-clearing task: a safety design challenge, IMECE2001/SERA-24004. In: Proceedings of 2001 ASME International Mechanical Engineering Congress and Exposition, (New York, NY, November 11-16, 2001), pp.1-6.

Fedan JS, Peppers JA, Johnston RA [2001]. Examination of the possible role of prostanoids on responses of guinea-pig isolated, perfused trachea (IPT) to luminally-applied isotonic osmolyte solutions. FASEB J 15(5):A862.

Franks JR [2001]. State of the art: new testing methods and passive hearing protectors. In: Henderson D, Prasher D, Kopke R, Salvi R, Hamernik R, eds. Noise Induced Hearing Loss: Basic Mechanisms, Prevention and Control. London, U.K.: Noise Research Network Publications, pp.187-195.

Franks JR [2001]. Chapter 8: Hearing measurement. In: Goelzer B, Hansen CH, Sehrndt GA, eds. Occupational exposure to noise: evaluation, prevention and control. Geneva, Switzerland: World Health Organization, pp.183-232.

Franks JR [2001]. NIOSH criteria document effectiveness measures. In: Proceedings of the Best Practices in Hearing Loss Prevention Conference, Detroit, MI: U.S. Department of Health and Human Services, Public Health Service, Centers for Disease Control and Prevention, National Institute for Occupational Safety and Health, pp.16-17.

Franks JR [2001]. The role of audiometric data management in hearing loss prevention: audiometric data management. In: Proceedings of the Best Practices in Hearing Loss Prevention Conference, Detroit, MI: U.S. Department of Health and Human Services, Public Health Service, Centers for Disease Control and Prevention, National Institute for Occupational Safety and Health, pp.41-42.

Frazer D, Tomblyn S, McKinney W, Friend KA, Goldsmith T [2001]. How does gas trapping at low lung volumes affect energy required to expand lung to total lung capacity? [Abstract]. Ann Biomed Eng 29(Suppl 1):S-143.

Friend K, Goldsmith T, McKinney W, Reynolds J, Watkins S, Frazer D [2001]. Higher order spectral analysis for excitation characterization in cough sounds [Abstract]. Ann Biomed Eng 29(Suppl 1):S-48.

Friend KA, Goldsmith WT, McKinney WH, Reynolds JS, Frazer D [2001]. Autoregressive model based on third order statistics for characterizing cough transmission filters [Abstract]. Ann Biomed Eng 29(Suppl 1):S-143. 


\section{Book Chapters/Proceedings/Abstracts/Technical Papers}

Gale WJ, Heasley KA, Iannacchione AT, Swanson PL, Hatherly P, King A [2001]. Rock damage characterization from microseismic monitoring. In: Elsworth D, Tinucci JP, Heasley KA, eds. Rock mechanics in the national interest. Vol. II. Lisse, Netherlands: Swets \& Zeitlinger, pp.1313-1320.

Gallagher S [2001]. Strength testing. In: Karwowski W, ed. International encyclopedia of ergonomics and human factors. Vol. 1. London, U.K.: Taylor \& Francis, Inc., pp.330-333.

Gao P, Boylstein PR, Berardinelli, Feather, SG, Hnizdo E, Kullman G [2001]. Measurement of airborne microorganisms and MVOCs at an elementary school in West Virginia. In: Book of Abstracts of the American Industrial Hygiene Conference \& Exposition. Fairfax, VA: American Industrial Hygiene Association, p. 320.

Geronilla KB, Miller GR, Mowery, KF, Cutlip RG [2001]. The mechanical and histological response of rat skeletal muscle to oscillatory contractions in vivo [Abstract]. Med \& Sci in Sports \& Exercise 33(5):S83.

Girard JM, McHugh EL [2001]. Emerging technologies and the future of geotechnical instrumentation. In: Elsworth D, Tinnucci JP, Heasley KA, eds. Rock Mechanics in the Public Interest. Proceedings of the 38th U.S. Rock Mechanics Symposium, DC Rocks, Vol. 1 (Washington, DC, July 7-10, 2001). Rotterdam: Balkema, pp.445-450.

Goldenhar L, Gershon R, Mueller C, Karkasian C, Swanson N [2001]. Psychosocial work stress in female funeral service practitioners. Chapter in Gender Work and Health 20:17-38

Goldsmith T, Afshari A, Azadi S, Jones B, Frazer D [2001]. A system for analyzing aerosols produced by humans during respiratory maneuvers [Abstract]. Ann Biomed Eng 29(Suppl 1): S-141.

Goodman GVR, Listak JM, Organiscak JA [2001]. An assessment of occupational silica exposures on continuous mining operations. SME Trans, Vol. 310. Littleton, CO: Society for Mining, Metallurgy, and Exploration, Inc.

Goodman GVR, Organiscak JA [2001]. Laboratory evaluation of a canopy air curtain for controlling occupational exposures of roof bolters. In: Proceedings of the Seventh International Mine Ventilation Congress (Krakow, Poland), pp.299-305.

Goodman GVR, Taylor CD, Colinet JF, Thimons ED [2001]. Research by NIOSH for controlling respirable dust and methane gas on continuous miner faces. In: Proceedings of the Seventh International Mine Ventilation Congress (Krakow, Poland), pp.237-241. 


\section{Book Chapters/Proceedings/Abstracts/Technical Papers}

Greenberg M., Nemhauser JB [2001]. Painful disorders of the hand and wrist in the clinical practice of emergency medicine. Edited by Ann Harwood-Nuss; Lippincott, Williams \& Wilkins, Philadelphia. Section II; Part VI, Chapter 54, pp.223-231.

Greskevitch MF, Ahlers H, Castranova V [2001]. Blasting abrasives' hazard comparison using in vivo data and respirable dust generating characteristics from environmentally controlled laboratory and field studies [Abstract]. In: Abstracts of the 2001 American Industrial Hygiene Conference \& Exposition. Fairfax, VA: American Industrial Hygiene Association, p.24.

Groce D, Bang K, Doney B, Young R [2001]. What's the difference? Comparing surveys of industrial respirator use. In: Book of Abstracts of the American Industrial Hygiene Conference \& Exposition. Fairfax, VA: American Industrial Hygiene Association, p.70.

Heasley KA, Ellenberger JL, Jeran PW [2001]. An analysis of rock failure around a deep longwall using microseismics. In: Peng SS, Mark C, Khair AW, eds. Proceedings of the 20th International Conference on Ground Control in Mining. Morgantown, WV: West Virginia University, pp.280-286.

Hebert MA, O’Callaghan JP [2001]. Phosphoprotein signaling associated with methamphetamine-induced glial activation [Abstract]. The Toxicologist 60(1):369.

Henneberger PK, Torén K, Hoffman CD, Sallsten G [2001]. Does current rather than cumulative dust exposure predict onset of asthma or chronic bronchitis among paper mill workers? [Abstract]. In: Hagsberg M, Knave B, Lillienberg L, Westberg H, eds. X2001 Exposure Assessment in Epidemiology and Practice Conference. Göteborg: Sweden, pp.321-323.

Henneberger PK, Cumro D, Deubner D, Kent MS, McCawley MA, Kreiss K [2001]. Beryllium sensitization and disease among workers in a ceramics plant [Abstract]. Am J Resp Crit Care Med 163(5):A242.

Hewett P [2001]. Industrial hygiene exposure assessment-data analysis and interpretation [Abstract]. In: Handbook of Chemical Health and Safety, San Diego, CA: American Chemical Society, pp.102-129.

Hewett P [2001]. Industrial hygiene exposure assessment-data collection and management [Abstract]. In: Handbook of Chemical Health and Safety, San Diego, CA: American Chemical Society, pp.81-101.

Higgins DN [2001]. Fatality Assessment and Control Evaluation (FACE) program:

Recommendations for preventing injuries and deaths of young workers [Abstract]. American Occupational Health Conference, April 20-27, p.21. 


\section{Book Chapters/Proceedings/Abstracts/Technical Papers}

Higgins DN, Parker DL, Wahl G [2001]. Recommendations for Preventing injury and death of workers using farm tractors to move large bales [Abstract]. National Institute for Farm Safety Annual Conference, June 24-27, p.24.

Hnizdo E, Chen J-Q, Attfield MD, Chen W, Gao P, Zhang J-Y, Wallace WE [2001]. Comparison of risk of silicosis in Chinese tin miners, tungsten miners and pottery workers [Abstract]. In: Proceedings of the International Symposium on Monitoring and Evaluation of Silica Dust Hazards. Wuhan, China: Huazhong University, pp.1-12.

Holden T, Ruff T [2001]. GPS-based proximity warning system for mining and construction equipment. In: Proceedings of the 14th International Technical Meeting of the Satellite Division of the Institute of Navigation (ION GPS 2001). (Salt Lake City, UT, September 11-14, 2001), pp.517-525.

Homce GT, Cawley JC, Yenchek MR, Sacks HK [2001]. An alarm to warn of overhead power line contact by mobile equipment. In: Conference Record of the 2001 IEEE Industry Applications Conference, 36th IAS Annual Meeting (Chicago, Illinois, September 30-October 4, 2001), 8p.

Hudock SD, Wurzelbacher SJ, Reed LD, Hales TR, Siegfried KV [2001]. Implementation of shipyard ergonomic interventions. In: Proceedings of the 2001 Ship Production Symposium, Ypsilanti, MI: The Society of Naval Architects and Marine Engineers, pp.1-10. CD-ROM.

Husberg BJ, Lincoln JM, Conway GA [2001]. On-deck dangers in the Alaskan commercial fishing industry. Proceedings of the Marine Safety Council. Vol. 58, No. 2, pp.23-24.

Hwang CC, Edwards JC [2001]. CFD modeling of smoke reversal. In: Proceedings of the International Conference on Engineered Fire Protection Design. Bethesda, MD: Society of Fire Protection Engineers, Inc., pp.376-387.

Iannacchione AT, Marshall TE, Burke L, Melville R, Litsenberger J [2001]. Safer mine layouts for underground stone mines subjected to excessive levels of horizontal stress. SME preprint 01-88. Littleton, CO: Society for Mining, Metallurgy, and Exploration, Inc., pp.1-7.

Iannacchione AT, Marshall TE, Prosser LJ Jr. [2001]. Failure characteristics of roof falls at an underground stone mine in southwestern Pennsylvania. In: Peng SS, Mark C, Khair AW, eds. Proceedings of the 20th International Conference on Ground Control in Mining. Morgantown, WV: West Virginia University, pp.119-125.

Jackson LL [2001]. Work-related injuries treated in U.S. emergency departments [Abstract]. Mobilizing for a SafeUSA. Atlanta, GA: p.54. 


\section{Book Chapters/Proceedings/Abstracts/Technical Papers}

Johnson EA, Miller DB [2001]. Restraint stress and other neuroprotective manipulations increase brain concentration of d-3,4-methylenedioxymethamphetamine (D-MDMA) in C57BL/6J mouse [Abstract]. The Toxicologist 60(1):344.

Johnston RA, Van Scott MR, Rengasamy A, Fedan JS [2001]. Effect of ion transport inhibitors on the bioelectric responses of guinea-pig tracheal epithelium to hypertonic sodium chloride solution [Abstract]. FASEB J 15(5):A861.

Johnston RA, Van Scott MR, Rengasamy A, Fedan JS [2001]. The effect of ion transport inhibitors on the bioelectric responses of guinea-pig tracheal-epithelium to hypertonic D-mannitol solution [Abstract]. Am J Respir Crit Care Med 163(5):A659.

Joseph P, Lei Y, Muchnok T, Ong T [2001]. DNA hypermethylation and loss of expression of the P16 tumor suppressor gene in cadmium transformed BALB/C-3T3 cells [Abstract]. Environ Molec Mutagenesis 37(32):41.

Joseph P, Muchnok TK, Klishis ML, Roberts JR, Antonini JM, Whong W-Z, Ong T [2001]. Cadmium-induced cell transformation and tumorigenesis are associated with transcriptional activation of C-FOS, C-JUN and C-MYC proto-oncogenes: role of cellular calcium and reactive oxygen species [Abstract]. The Toxicologist 60(1):31.

Joseph P, Lei Y, Ong T [2001]. Translation elongation factor 1 delta sub-unit is a novel cadmium-responsive proto-oncogene [Abstract]. Mutat Res 483 (Suppl 1):S77.

Joseph P, Ong T-M [2001]. Gene expression in BALB/c-3T3 cells transformed with beryllium [Abstract]. Nature Genetics 27:62.

Karol MH, Matheson JM, Lemus R, Lange RW, Luster MI [2001]. Lack of association of antibodies with diisocyanate-induced airway inflammation, hyperreactivity and asthma [Abstract]. The Toxicologist 60(1):8.

Keshava N, Lin F, Chen ZY, Huffman D, Ong T [2001]. Tumorigenic potential of metal working fluid induced in BALB/C-3T3 transformed cells [Abstract]. Environ Molec Mutagenesis $37(32): 43$

Keshava N, Lin F, Huffman D, Chen Z-Y, Ong T [2001]. Cell transformation and gene expression induced by metal working fluid in BALB/C-3T3 cells [Abstract]. Environ Molec Mutagenesis 37(32):42.

Keshava N, Lin F, Whong W-Z, Ong T [2001]. Potential of tetrachloroethylene to induce genetic alterations and carcinogenesis [Abstract]. The Toxicologist 60(1):153. 


\section{Book Chapters/Proceedings/Abstracts/Technical Papers}

Keshava N, Lin F, Whong W-Z, Ong T-M [2001]. Transforming and tumorigenic potential of tetrachloroethylene in BALB/c-3T3 cells [Abstract]. Mutat Res 483(Suppl 1):S83.

Kinneer-DeFede K, Ye J, Luster M, Ma Q [2001]. Inhibition of LPS-induced TNF- $\alpha$ expression by phenolic antioxidants [Abstract]. The Toxicologist 60(1):180.

Kisin E, Smith C, Murray A, Kisin J, Kommineni C, Castranova V, Kagan VE, Shvedova AA [2001]. Phenolic compounds cause depletion of GSH, oxidative stress and cytotoxicity in normal human dermal cells [Abstract]. The Toxicologist 60(1):169.

Kissell FN, Colinet JF [2001]. Control of respirable dust. In: Karmis M, ed. Mine health and safety management. Littleton, CO: Society for Mining, Metallurgy, and Exploration, Inc., pp.275-295.

Kissell FN, Thimons ED [2001]. Test report on the machine-mounted continuous respirable dust monitor. In: Proceedings of the Seventh International Mine Ventilation Congress (Krakow, Poland), pp.253-260.

Kommineni C, Shvedova AA, Al-Humadi NH [2001]. Used semi-synthetic metal working fluid (UMWF): dermal and systemic effects in B6C3F1 mice [Abstract]. The Toxicologist 60(1):59.

Kowalski KM, Vaught C [2001]. Judgment and decision-making under stress: an overview for emergency managers. In: Proceedings of The International Emergency Management Society (TIEMS) Conference (Oslo, Norway). CD-ROM.

Larson MK and Iverson SR [July 2001]. Application of particle flow code to evaluate a concept for detecting hazardous voids in surge piles using profile scanning. In: Elsworth D, Tinnucci JP, Heasley KA, eds. Rock Mechanics in the Public Interest. Proceedings of the 38th U.S. Rock Mechanics Symposium, DC Rocks, Vol. 1 (Washington, DC, July 7-10, 2001). Rotterdam: Balkema, pp.459-465.

Lawrence, RB, Coffey, CC, Zhuang, Z, Campbell, DL [2001]. The ability of five fit-test methods to screen out poorly fitting N95 filtering-facepiece respirator. In: Book of Abstracts of the American Industrial Hygiene Conference \& Exposition. Fairfax, VA: American Industrial Hygiene Association, (Orlando, FL, May 20-25, 2000), p.69.

Layne LA, Jackson LL, Chen GX [2001]. Occupational injury and illness requiring hospitalization [Abstract]. 2001 Congress of Epidemiology. Am J Epidemiol 153(11):s76.

Lentz T, Zumwalde R, MacMahon K, Dement J, Kojola W, Crane A, Calzavara T, Venturin D, Hacker S, Finkel A [2001]. Synthetic fibers in the workplace: where less fiber is healthier. American Industrial Hygiene Association \& Exposition. Fairfax, VA. (Orlando, FL, May 20-25, 2000). 


\section{Book Chapters/Proceedings/Abstracts/Technical Papers}

Lewis DM [2001]. Pulmonary Immunotoxicology [book review]. N Engl J Med 345(8):624.

Li F, Huston RL, Waters TR [2001]. Musculoskeletal dynamics of heavy equipment operators. In: Proceedings of the International Conference on Computer-Aided Ergonomics and Safety, Maui, HI: International Ergonomics Association. CD-ROM.

Linch K, Miller W [2001]. Generation of respirable quartz dust from masonry sawing [Abstract]. In: Abstracts of the 2001 American Industrial Hygiene Conference \& Exposition (New Orleans, LA, June 2-7, 2001). Morgantown, WV: p.49.

Lindsley WG, Johnson CM, Cezeaux JL, Kashon ML [2001]. Effect of vibration on IL-8 production by dermal microvascular endothelial cells [Abstract]. Annals Biomed Eng 29(Suppl 1):S-41.

Listak JM, Chekan GJ, Colinet JF [2001]. Laboratory evaluation of shield dust entrainment in high-velocity airstreams. SME preprint 01-144. Littleton, CO: Society for Mining, Metallurgy, and Exploration, Inc., pp.155-160.

Little AR, O'Callaghan JP [2001]. MCP-1 is elevated in hippocampus after trimethyl tin (TMT)induced neuronal damage: biomarker of neural injury? [Abstract]. The Toxicologist 60(1):189.

Luster MI [2001]. Ozone-induced mucous cell metaplasia [toxicological highlight]. Toxicol Sci 60(2):193.

Luster MI, Simeonova PP [2001]. Proposed mechanisms of arsenic toxicity carcinogenesis. In: Fuchs J, Packer L, eds. Environmental stressors in health and disease. Vol. 1. New York: Marcel Dekker, Inc., pp.103-114.

Ma JY, Frazer D, Barger MW, Tomblyn S, Stone S, Robinson VA, Castranova V [2001]. Effects of asphalt fume exposure on the pulmonary cytochrome P450 systems [Abstract]. The Toxicologist 60(1):427.

Ma JYC, Kane E, Barger MW, Castranova V [2001]. Effects of diesel exhaust particles (DEP) exposure on pulmonary cytochrome P-450 (P-450) metabolism [Abstract]. Am J Respir Crit Care Med 163(5):A172.

Ma JYC, Rengasamy A, Barger MW, Kane E, Ma JKH, Castranova V [2001]. Alteration of pulmonary cytochrome P-450 system by diesel exhaust particles [Abstract]. Toxicol 164(1-3):119.

Ma Q, De Fede K, Baldwin KT, Burdette HE [2001]. Interactions of the AH receptor and oxidative signaling [Abstract]. Dioxin 2001 53:336-339. 


\section{Book Chapters/Proceedings/Abstracts/Technical Papers}

Ma Q, Kinneer De-Fede K [2001]. A labile factor regulates induction of NQOR by TCDD and phenolic antioxidants [Abstract]. The Toxicologist 60(1):364.

MacLaughlin MM, Langston RB, Brady TM [2001]. Numerical geomechanical modeling for the Stillwater Mine, Nye, Montana. In: Elsworth D, Tinnucci JP, Heasley LA, eds. Rock Mechanics in the Public Interest. Proceedings of the 38th U.S. Rock Mechanics Symposium, DC Rocks, Vol. 1 (Washington, DC, July 7-10, 2001). Rotterdam: Balkema, pp.423-432.

Maleki H, Owens J [2001]. Application of computational and statistical techniques to an evaluation of mobile roof supports. In: Computer Methods and Advances in Geomechanics. Proceedings of the 10th International Conference on Computer Methods and Advances in Geomechanics, Vol. 2 (Tucson, AZ, January 7-12, 2001). pp.1705-1711.

Maleki H, Owens J, and Endicott M [2001]. Evaluation of mobile roof support technologies. In: Peng SS, Mark C, Khair AW, eds. Proceedings: 20th International Conference on Ground Control in Mining (Morgantown WV, Aug. 7-9, 2001). Morgantown, WV: West Virginia University, pp.67-77.

Mark C [2001]. Focus on ground control: horizontal stress. Coal Age 106(3):47-51.

Mark C [2001]. Overview of ground control research for underground coal mines in the United States. In: Proceedings of the 17th International Mining Congress and Exhibition of Turkey (IMCET 2001) (Ankara, Turkey), pp.3-10.

Mark C [2001]. Overview of ground control research for underground coal mines in the United States. In: Proceedings of the 29th International Conference of Safety in Mines Research Institutes. Vol. 2. Katowice, Poland: Central Mining Institute, pp.251-261.

Mark C, Iannacchione AT [2001]. Ground control issues for safety professionals. In: Karmis M, ed. Mine health and safety management. Littleton, CO: Society for Mining, Metallurgy, and Exploration, Inc., pp.347-367.

Mark C, Molinda GM, Dolinar DR [2001]. Analysis of roof bolt systems. In: Peng SS, Mark C, Khair AW, eds. Proceedings of the 20th International Conference on Ground Control in Mining. Morgantown, WV: West Virginia University, pp.218-225.

Mark C, Zelanko JC [2001]. Sizing of final stumps for safer pillar extraction. In: Peng SS, Mark C, Khair AW, eds. Proceedings of the 20th International Conference on Ground Control in Mining. Morgantown, WV: West Virginia University, pp.59-66.

Mark R, Richards R, Mark C [2001]. Geomechanics of large stone structures: a case history from the Washington national cathedral. In: Proceedings of the 38th U.S. Rock Mechanics Symposium, pp.1055-1061. 


\section{Book Chapters/Proceedings/Abstracts/Technical Papers}

Martin LA, Dreesbach CA, Pakalnis R [2001]. Evaluation of instrumented cable and rebar bolts as ground support at a trona mine. In: Peng SS, Mark C, and Khair AW, eds. Proceedings of the 20th International Conference on Ground Control in Mining (Morgantown WV, Aug. 7-9, 2001). Morgantown, WV: West Virginia University, pp.309-316.

Martin L, Pakalnis R, Curtin RP [2001]. Case studies of cable bolts using instrumented king wires. In: Elsworth D, Tinnucci JP, Heasley KA, eds. Rock Mechanics in the Public Interest. Proceedings of the 38th U.S. Rock Mechanics Symposium, DC Rocks, Vol. 1 (Washington, DC, July 7-10, 2001). Rotterdam: Balkema, pp.1013-1020.

Martinez K, Trout D, Kanwal R [2001]. Bioaerosols in industrial settings. The Encyclopedia of Environmental Microbiology. John Wiley \& Sons, Inc. 1:416-425.

Matheson JM, Lange RW, Lemus R, Karol MH, Luster MI [2001]. The role of tumor necrosis factor (TNF) $\alpha$ in toluene diisocyanate (TDI) asthma [Abstract]. The Toxicologist 60(1):174.

Maynard AD, Jensen PA [2001]. Chapter 25: Aerosol measurement in the workplace. In: Baron PA, Willeke K, eds. Aerosol measurement: principles, techniques, and applications. 2nd ed. New York, NY: John Wiley and Sons, Inc., pp.779-799.

McFall M [2001]. Roadway assistance. Fire Chief 45(3):62-64.

McHugh EL, Girard JM, Denes LJ [2001]. Simplified hyperspectral imaging for improved geologic mapping of mine slopes. In: Meech JA, Veiga SM, Viega MM, LeClair SR, Maguire JF, eds. Proceedings of the Third International Conference on Intelligent Processing and Manufacturing of Materials (Vancouver, British Columbia, Canada, July 29-Aug 2). CD-ROM.

McKenzie E, Powers J, Harris J, Ronaghi M, Etherton J, Current R, Cantis D, Newbraugh B, Lutz T [2001]. Continuing developments at NIOSH on ROPS for agricultural tractors.

Proceedings of National Institute for Farm Safety Annual Conference, Pittsburgh, Pennsylvania, June 24-27.

Mercer RR, Millecchia L, Wang L, Scabilloni JF, Castranova V [2001]. Induction of apoptosis by chronically inhaled silica [Abstract]. The Toxicologist 60(1):81.

Miller AL, King GW, Savanik GA [2001]. Waterjet cleaning of truck-mounted concrete mixing tanks. In: Hashish M, ed. Proceedings of the 2001 WJTA American Waterjet Conference, (Minneapolis, MN, August 18-21, 2001), Vol. 2, paper 40. Waterjet Technology Assoc., pp.551-565.

Minhas NS, Battelli LA, Porter DW, Goldsmith T, Dotson A, Jones W, Greskevitch M, Ma J, Hubbs AF [2001]. Pulmonary inflammation after intratracheal instillation of abrasive blasting agents [Abstract]. Toxicol Sci Suppl - The Toxicologist 60:190. 


\section{Book Chapters/Proceedings/Abstracts/Technical Papers}

Morata TC, Campo P [2001]. Auditory function after single or combined exposure to styrene: a review. In: Henderson D, Prasher D, Kopke R, Salvi R, Hamernik R, eds. Noise-induced hearing loss: basic mechanisms, prevention and control. London, U.K.: Noise Research Network Publications, pp.293-304.

Morata TC, Lemasters G [2001]. Consideracoes epidemiologicas para o estudo de perdas auditivas ocupacionais (Epidemiologic considerations in the evaluation of occupational hearing loss). In: Costa E, Ibanez R, Nudelmann A, Seligman J, eds. Perda auditiva induzida pelo ruido II (Noise-induced hearing loss II). Vol. II. Rio de Janeiro: Livraria e Editora Revinter, pp.1-16.

Mulvey T, Satterfield BE, Frazer DG, Fedan JS, Dey RD [2001]. Effects of ozone re-exposure on substance P (SP)-innervation in airways of postnatal rats [Abstract]. Am J Respir Crit Care Med 163(5):A824.

Murono EP, Derk RC, de Leon JH [2001]. Differential effects of 4-tert-octylphenol (OP), $17 \beta$-estradiol (E2), bisphenol A (BIS), or endosulphan (ENDO) on steroidogenic competence of cultured adult rat leydig cells (LC) [Abstract]. The Toxicologist 60(1):73.

Murray A, Kisin E, Castranova V, Kommineni C, Gunter MR, Shvedova AA [2001]. Phenol induced in vivo oxidative stress in skin: evidence for enhanced free radical generation, thiol oxidation and antioxidant depletion [Abstract]. The Toxicologist 60(1):42.

Murthy L, Dankovic DA, Murthy R [2001]. Titanium, zirconium, and hafnium. In: Bingham E, Cohrssen B, Powell CH, eds. Patty's Toxicology, Vol. 2, Fifth Edition. New York, NY: John Wiley \& Sons, pp.677-745.

Nelson J, Soderholm S, Greskevitch MF [2001]. Controlling respirable quartz dust in sandblasting: role of sand particle size and a dust suppression agent [Abstract]. In: Abstracts of the American Industrial Hygiene Conference \& Exposition (New Orleans, LA, June 2-7, 2001), p.55.

Organiscak JA, Cecala AB, Heitbrink WA, Thimons ED, Schnitz M, Ahrenholtz E [2001]. Field assessment of retrofitting surface coal mine equipment cabs with air filtration systems. In: Bockosh GR, Karmis M, Langton J, McCarter MK, Rowe B, eds. Proceedings of the 31st Annual Institute of Mining Health, Safety and Research. Blacksburg, VA: Virginia Polytechnic Institute and State University, Department of Mining and Minerals Engineering, pp.57-68.

Orr TJ, Filigenzi MT, Ruff TM [2001]. Hazard recognition - computer-based simulation. In: Jenkins FM, Langton J, McCarter MK, Rowe B, eds. Proceedings of the 30th Annual Institute on Mining Health, Safety, and Research (Salt Lake City, UT, August 8-11, 1999). Blacksburg, VA: Department of Mining and Minerals Engineering, Virginia Polytechnic Institute and State University, pp.21-28. 


\section{Book Chapters/Proceedings/Abstracts/Technical Papers}

Oyler DC [2001]. Development and use of a high-pressure packer for measuring horizontal stress using the hydraulic fracturing method. In: Elsworth D, Tinucci JP, Heasley KA, eds. Rock mechanics in the national interest. Vol. I. Lisse, Netherlands: Swets \& Zeitlinger, pp.227-234.

Oyler DC, Hasenfus G, Molinda GM [2001]. Load and deflection response of ventilation stoppings to longwall abutment loading: a case study. In: Peng SS, Mark C, Khair AW, eds. Proceedings of the 20th International Conference on Ground Control in Mining. Morgantown, WV: West Virginia University, pp.34-41.

Palassis J, Bryant J, Zey J [2001]. Chapter 17: Detector tubes, direct-reading passive badges, and dosimeter tubes, part of the 9th edition of air sampling instruments book of ACGIH, a graduate school textbook and a reference book in industrial hygiene and occupational safety. ACGIH, Cincinnati, OH, May 2001, pp.457-509.

Pan CS, Chiou S, Long D, Zwiener J, Cantis D [2001]. Kinematic analysis of drywall lifting. In: Bittner A, ed. The 15th Annual Conference of the International Society for Occupational Ergonomics and Safety. Vol. 4. Fairfax, VA: Advances in Occupational Ergonomics and Safety, pp.62-69.

Pappas DM, Prosser LJ Jr. [2001]. An overview of groundfall injuries and worker activity in underground stone mines. MSHA Holmes Safety Association Bulletin Aug:8-14.

Park J, Robertson A, Garuccio C, Cyphers D, Miller R, Cutlip RG, Wirth O [2001]. Effects of varying work-rest cycles of downhill running on acute muscle injury in rats [Abstract]. Med \& Sci in Sports \& Exercise 33(5):S121.

Pedersen DH, Young RO, Rose VE [2001]. Chapter 110: Populations at Risk. Patty's Toxicology, Fifth Edition, Vol. VIII, pp.699-1080.

Peng SS, Finfinger GL [2001]. Geology roof control and mine design. Coal Age 106(12):29-31.

Poirier MC, Weston A [2001]. Carcinogen macromolecular adducts. In: Reuss W, ed. Springer Encyclopedic Reference of Cancer. Heidelberg FRG: Springer-Verlag, pp.157-162.

Porter DW, Robinson VA, Battelli LA, Hubbs AF, Greskevitch MF, Jones WG, Castranova V [2001]. Pulmonary inflammation after intratracheal instillation of abrasive blasting substitutes [Abstract]. The Toxicologist 60(1):190.

Qiao GL, Riviere JE [2001]. Significant effects of application vehicle, skin occlusion, cutaneous CYP450 induction, and ambient temperature on dermal absorption and cutaneous disposition of pentachlorophenol (PCP) [Abstract]. The Toxicologist 60(1):60. 


\section{Book Chapters/Proceedings/Abstracts/Technical Papers}

Rakheja S, Wu J, Dong R, Boileau PE, Schopper AW [2001]. On the applications of biodynamic models of the human hand and arm [Abstract]. In: Abstracts of the 9th International Conference on Hand-Arm Vibration Session 3, (Nancy, France, June 5-8, 2001).

Ramani RV, Mutmansky JM, Honglin H, Volkwein JC, Marple VA, Olson BA, et al. [2001]. A comparative evaluation of the differential-pressure-based respirable dust dosimeter with the personal gravimetric respirable dust sampler in underground coal mines. In: Proceedings of the Seventh International Mine Ventilation Congress (Krakow, Poland), pp.243-251.

Rao CY, Hirvonen MR, Burge HA, Brain JD [2001]. Nitric oxide and proinflammatory cytokines in the bronchoalveolar lavage fluid of rats after intratracheal instillation of toxic Stachybotrys chartarum spores [Abstract]. Am J Resp Crit Care Med 163(5):A177.

Rehak TR, Bajpayee TS, Mowrey GL, Ingram DK [2001]. Flyrock issues in blasting. In: Proceedings of the 27th Annual Conference on Explosives and Blasting Technique. Vol. I. Cleveland, OH: International Society of Explosives Engineers, pp.165-175.

Reynolds JS, Stemple KJ, Petsko RA, Ebeling TR, Frazer DG [2001]. Nonlinear modeling of a pulmonary waveform generator [Abstract]. Ann Biomed Eng 29(Suppl 1):S-142.

Reynolds J, Stolarik B, Friend K, Frazer D [2001]. Transfer function analysis of respiration of laboratory animals [Abstract]. Ann Biomed Eng 29(Suppl 1):S-48.

Rider JP, Colinet JF [2001]. Reducing worker exposure to dust generated during longwall mining. In: Proceedings of the Seventh International Mine Ventilation Congress (Krakow, Poland), pp.275-282.

Rider JP, Colinet JF, Chekan GJ, Listak JM, Thimons ED [2001]. Longwall dust control: issues and possible solutions. In: Proceedings of Longwall USA International Exhibition \& Conference. Overland Park, KS: Intertec Publishing Corp., pp.91-111.

Rider JP, Colinet JF, Prokop AE [2001]. Impact of control parameters on shearer-generated dust levels. SME preprint 01-184. Littleton, CO: Society for Mining, Metallurgy, and Exploration, Inc.

Roberts JR, Clarke RW, Antonini JM [2001]. Soluble metals in residual oil fly ash suppress lung defense mechanisms and elevate acute mortality after infection [Abstract]. Am J Respir Crit Care Med 163(5):A495.

Robinson VA, Young S, Barger M, Porter DW, Goldsmith R, Frazer DG, Castranova V [2001]. Acute inflammation and recovery in rats after intratracheal instillation of A $1 \rightarrow 3$ - $\beta$-glucan (Zymosan A) [Abstract]. The Toxicologist 60(1):197. 


\section{Book Chapters/Proceedings/Abstracts/Technical Papers}

Ronaghi M, Current R, Etherton J [2001]. Research on the use of composite materials in ROPS. In: Proceedings of National Institute for Farm Safety Annual Conference (Pittsburgh, PA, June 24-27, 2001).

Rosa RR [2001]. Examining work schedules for fatigue: it's not just hours of work. In: Hancock PA, Desmond PA, eds. Stress, workload, and fatigue. Mahwah, NJ: Lawrence Earlbaum Associates, pp.513-528.

Rosenstock L, Jackson Lee L [2001]. Needlestick injuries and health care workers: the U.S. experience. In: Hospital Management International. London, U.K.: International Hospital Federation, pp.83-86.

Rowland JH III, Mainiero RJ, Hurd DA Jr. [2001]. Factors affecting fumes production of an emulsion and ANFO/emulsion blends. In: Proceedings of the 27th Annual Conference on Explosives and Blasting Technique. Vol. II. Cleveland, OH: International Society of Explosives Engineers, pp.133-141.

Sapko MJ, Weiss ES [2001]. Evaluation of new methods and facilities to test explosion-resistant seals. In: Proceedings of the 29th International Conference of Safety in Mines Research Institutes. Vol. 1. Katowice, Poland: Central Mining Institute, pp.157-166.

Sargent LM [2001]. Role of polychlorinated biphenyl exposure in the progression of neoplasia. In: Robertson LW, Hansen LG, eds. PCBs. Lexington, KY: University Press of Kentucky, pp.373-379.

Scabilloni JF, Wang L, Ramsey DM, McLaurin J, Castranova V, Mercer RR [2001]. Matrix metalloproteinase-induction in fibrosis and fibrotic nodule formation due to silica inhalation [Abstract]. Am J Respir Crit Care Med 163(5):A169.

Schachter EN, Zuskin E, Rienzi N, Goswami S, Castranova V, Siegel P, Whitmer M, Skloot G, Chung E [2001]. Pharmacological characterization of an extract of wheat grain [Abstract]. Am J Respir Crit Care Med 163(5):A845.

Schiffbauer WH [2001]. An active proximity warning system for surface and underground mining applications. SME preprint 01-117. Littleton, CO: Society for Mining, Metallurgy, and Exploration, Inc.

Schiffbauer WH, Mowrey GL [2001]. An environmentally robust proximity warning system for hazardous areas. In: Proceedings of the ISA Emerging Technologies Conference. Research Triangle Park, NC: Instrumentation, Systems, and Automation Society. 


\section{Book Chapters/Proceedings/Abstracts/Technical Papers}

Schmechel D, Lewis DM [2001]. The production of species-specific monoclonal antibodies (Mabs) against the allergenic and toxigenic fungus Stachybotrys chartarum [Abstract]. FASEB J 15(4):A662.

Schmechel D, Simpson JP, Lewis DM [2001]. Evaluation of cross-reactivities among airborne fungi using monoclonal antibodies [Abstract]. J Allerg Clin Immunol 107(2):S26.

Schopper AW, Miller R, Cutlip RG, Lindsley W, Wirth O [2001]. Physical work may be risky-but why? The underlying pathomechanics of musculoskeletal injury. In: Bittner AC Jr., Champney PC, Morrissey SJ, eds. Proceedings of the 15th Annual Conference of the International Society for Occupational Ergonomics and Safety, Advances in occupational ergonomics and safety, Vol. 4: Amsterdam, the Netherlands, pp.387-393.

Schuh RA, Carter JC, O'Callaghan JP, Jett DA [2001]. Neurochemical correlates of cognitive deficits in weanling rats exposed to chlorpyrifos [Abstract]. The Toxicologist 60(1):241.

Schuler CR, Deubner D, Henneberger PK, Kreiss K [2001]. Population-based risk of beryllium disease at a beryllium copper alloy plant [Abstract]. Am J Resp Crit Care Med 163(5):A242.

Schulte P, Stayner L, Okun A [2001]. Comparative epidemiology of two potential hazards: threshold for public health action [Abstract]. Am J Epidemiol 153:5270.

Schweitzer PK, Randazzo AC, Stone KL, Walsh JK [2001]. Alertness and performance on simulated night shifts following evening naps. Sleep 24:A423.

Schweitzer PK, Walsh JK [2001]. Evening naps reduce daytime sleep on a simulated night shift. Sleep 24:A124.

Scott AE, Yucesoy B, Luster MI, Kashon M, Tinkle SS [2001]. Local lymph node assay as a quantitative risk assessment tool to model biologic skin response of allergic contact dermatitis in the mouse [Abstract]. The Toxicologist 60(1):170.

Shastri V, Wirth O, Cutlip RG [2001]. A model for controlling and quantifying volitional muscle performance of rat plantar flexors in vivo [Abstract]. Med \& Sci in Sports \& Exercise 33(5):S295.

Shi X, Ding M, Chen F, Vallyathan V, Castranova V [2001]. Reactive oxygen species and silicainduced carcinogenesis. In: Fuchs J, Packer L, eds. Environmental stressors in health and disease. Vol. 1. New York: Marcel Dekker, Inc., pp.203-224. 


\section{Book Chapters/Proceedings/Abstracts/Technical Papers}

Shulman SA, Smith JP [2001]. Estimation of bias and variability of continuous gas monitor data: application to carbon monoxide monitor accuracy. Cincinnati, OH: U.S. Department of Health and Human Services, Public Health Service, Centers for Disease Control and Prevention, National Institute for Occupational Safety and Health, submitted to EPHB-005-128.

Signer SP, Rains R [2001]. A case study of bolt loads in a trona mine retreat section. In: Roofbolting in Mining, Aachen International Mining Symposia (Aachen, Germany, June 6-7, 2001). Aachen, Germany: Institut für Bergbaukunde I, pp.481-494.

Signer SP, Rains R [2001]. Effects of bolt spacing, bolt length, and roof span on bolt loading in a trona mine. In: Peng SS, Mark C, Khair AW, eds. Proceedings of the 20th International Conference on Ground Control in Mining (Morgantown, WV, August 7-9, 2001). Morgantown, WV: West Virginia University, pp.302-308.

Simeonova PP, Wang S, Hulderman T, Luster MI [2001]. Arsenic-induced gene expression in urinary bladder epithelium [Abstract]. The Toxicologist 60(1):204.

Smith C, Kisin E, Murray A, Castranova V, Kommineni C, Shvedova AA [2001]. Enhanced oxidative stress in the skin of vitamin E-deficient mice exposed to metal working fluid [Abstract]. The Toxicologist 60(1):60.

Smutz WP, Dong RG, Schopper AW [2001]. A study of tissue vibration transmissibility using a scanning laser vibrometer. In: Proceedings of the 25th Annual Meeting of the American Society of Biomechanics, San Diego, CA, pp.413-414.

Snawder JE, Butler MA, Clark JC, Knecht EA, Krieg EF Jr. [2001]. Sensitive early indicators of hepatic and kidney damage in workers exposed to jet fuel (JP-8). In: JP8: Final Risk Assessment. Lubbock, TX: The Institute of Environmental and Human Health, pp.81-86.

Soderholm SC [2001]. Particle and gas phase interactions in air sampling. In: Cohen BS, McCammon CS, eds. Air sampling instruments. 9th ed. Cincinnati, OH: ACGIH Worldwide, pp.77-92.

Sriram K, O’Callaghan JP [2001]. Leptin-deficient (OB/OB) condition exacerbates neurodegeneration [Abstract]. The Toxicologist 60(1):368.

Sriram K, O’Callaghan JP [2001]. Obesity as a potential risk factor for dopaminergic neurotoxicity [Abstract]. Neurotoxicology 22(6):82.

Stayner L [2001]. Introduction to risk assessment. In: Alaimo RJ, ed. Handbook of Chemical Safety and Health. New York, NY: Oxford University Press, pp.63-67. 


\section{Book Chapters/Proceedings/Abstracts/Technical Papers}

Steiner LJ, Vaught C [2001]. Work design: barriers facing the integration of ergonomics into system design. In: Karwowski W, ed. International encyclopedia of ergonomics and human factors. Vol. II. London, U.K.: Taylor \& Francis, Inc., pp.1437-1440.

Stewart B, Clark C, Patton P [2001]. Materials-handling accident reduction in underground mines. In: 6th International Symposium on Mine Mechanization and Automation (Johannesburg, Republic of South Africa, September 25-28, 2001), Symp. Series 528. Republic of South Africa, Johannesburg: South African Institute for Mining and Metallurgy, pp.11-17.

Sugawara T, Gallucci RM, Simeonova PP, Luster MI [2001]. Interleukin 1-dependent regulation of interleukin 6 production by wounding in human epithelial keratinocyte [Abstract]. The Toxicologist 60(1):176.

Swanson P [2001]. Development of an automated PC-network-based seismic monitoring system. In: van Aswegen G, Durrheim RJ, Orlepp WD, eds. Proceedings of the 5th International Symposium on Rockbursts and Seismicity in Mines (Johannesburg, Republic of South Africa, September 17-19, 2001). Johannesburg, Republic of South Africa: South African Institute for Mining and Metallurgy, pp.11-17.

Swanson P, Krahanbuhl T, Kenner B [2001]. Large-strain monitoring above a longwall coal mine with GPS and seismic measurements [Abstract]. EOS, Trans Am Geophys Union 82(17):864.

Swanson NG, Sommerich C, Alderson M, Dunkin R [2001]. The relationship between keyboard and mouse use and musculoskeletal symptoms. In: Proceedings of the International Conference on Computer-Aided Ergonomics and Safety, Maui, HI: International Ergonomics Association. CD-ROM.

Tadolini SC, Dolinar DR [2001]. Enhanced surface control for roof and rib support. In: Peng SS, Mark C, Khair AW, eds. Proceedings of the 20th International Conference on Ground Control in Mining. Morgantown, WV: West Virginia University, pp.173-179.

Taylor CD, Thimons ED, Zimmer JA [2001]. Factors affecting the location of methanometers on mining equipment. In: Proceedings of the Seventh International Mine Ventilation Congress (Krakow, Poland), pp.683-688.

Taylor CD, Zimmer JA [2001]. Effects of water sprays and scrubber exhaust on face methane concentrations. In: Proceedings of the Seventh International Mine Ventilation Congress (Krakow, Poland), pp.465-470.

Taylor CD, Zimmer JA [2001]. Effects of water sprays used with a machine-mounted scrubber on face methane concentrations. SME preprint 01-114. Littleton, CO: Society for Mining, Metallurgy, and Exploration, Inc. 


\section{Book Chapters/Proceedings/Abstracts/Technical Papers}

Taylor MD, Antonini JM, Roberts JR, Van Dyke K, Bowman LL, Castranova V, Hubbs AF, Shi X, Leonard SS, Reasor MJ [2001]. Intratracheal amiodarone administration to F344 rats causes acute damage to airway and parenchymal cells: the possible role of free radical generation [Abstract]. The Toxicologist 60(1):424.

Taylor MD, Roberts JR, Hubbs AF, Reasor MJ, Antonini JM [2001]. Application of laser scanning confocal microscopy in the analysis of drug-induced lung fibrosis [Abstract]. Am J Respir Crit Care Med 163(5):A716.

Trutt FC, Sottile J, Kohler JL [2001]. On-line condition monitoring of induction motors. In: Conference Record of the 2001 IEEE Industry Applications Conference, 36th IAS Annual Meeting (Chicago, IL), pp.1369-1375.

Volkwein JC, Thimons ED [2001]. New tools to monitor personal exposure to respirable coal mine dust. In: Proceedings of the Seventh International Mine Ventilation Congress (Krakow, Poland), pp.143-150.

Vollmer WM, O’Connor EA, Heumann MA, Breen VA, Villnave JM, Frazier EA, Buist AS, Henneberger PK [2001]. Incidence of occupational asthma (OA) in an adult managed care population [Abstract]. Am J Resp Crit Care Med 163(5):A161.

Wang J, Frazer DG, Goldsmith T, Tomblyn S, Simpson J, Stone S, Afshari A, Lewis DM, Castranova V, Siegel PD [2001]. Characterization of an asphalt fume generation system and determination of fume compositions at simulated road paving conditions [Abstract]. The Toxicologist 60(1):20-21

Wang J, Frazer DG, Tomblyn S, Stone S, Afshari A, Zhong BZ, Lewis DM, Siegle PD [2001]. Characterization of asphalt fume generation system [Abstract]. The Toxicologist 60(1):351.

Wang L, Antonini JM, Rojanasakul Y, Castranova V, Scabilloni JF, Mercer RR [2001]. Role of macrophage apoptosis in pulmonary inflammation [Abstract]. The Toxicologist 60(1):81.

Wang ML, Petsonk EL [2001]. Symptom onset in the first two years of employment at a wood products plant: some observations relevant to occupational medical screening. Am J Respir Crit Care Med 163(5):A810.

Wang ML, Petsonk EL, Wagner GR [2001]. Pneumoconiosis prevalence among working U.S. coal miners: Preliminary results based on chest X-ray screening data, 1995 to 2000 . Am J Epidemiol 153(11):S127.

Wang RC, McKewan WM [2001]. A model for the structure of round-strand wire ropes. Organisation Internationale pour l'Etude de l'Endurance des Cables (OIPEEC) (International Organisation for the Study of the Endurance of Ropes), Bulletin 81. Reading, U.K.: Reading Rope Research, Department of Engineering, University of Reading, pp.15-42. 


\section{Book Chapters/Proceedings/Abstracts/Technical Papers}

Wassell JT [2001]. Bootstrap methods: a practitioner's guide [Book Review]. Technometrics 43(1) February 1, 2001.

Waters TR [2001]. Computer-based training program for the revised NIOSH lifting equation. In: Proceedings of the International Conference on Computer-Aided Ergonomics and Safety, Maui, HI: International Ergonomics Association. CD-ROM.

Weissman DN, Seigel PD, Zhuang Z, Lewis DM [2001]. Augmentation of inflammatory and immune responses to inhaled antigen by combined exposure to Beta-nephthoflavone (BNF) [Abstract]. J Allerg Clin Immunol 107(2):S146.

Welcome D, Rakheja S, Dong RG, Westfall, B, Schopper AW [2001]. A preliminary study of the relationship of hand grip and push forces to total coupling forces. In: Cox LN, Arrowsmith CI, Holmes SR, eds. Proceedings of the 36th UK Group Conference on Human Response to Vibration, Farnborough, U.K., pp.368-375.

Westman EC, Heasley KA, Swanson PL, Peterson S [2001]. A correlation between seismic tomography, seismic events and support pressure. In: Elsworth D, Tinucci JP, Heasley KA, eds. Rock mechanics in the national interest. Vol. I. Lisse, Netherlands: Swets \& Zeitlinger, pp.319-326.

Weston A, Ensey J, Kreiss K, Keshava C, McCanlies E [2001]. Evaluation of a supratypic HLAgenetic marker for susceptibility to chronic beryllium disease: racial variation has no significant impact for pre-employment screening [Abstract]. Am J Human Genetics 69(4):444.

Whyatt JK [2001]. A method for modeling variation of in situ stress related to lithology. In: Elsworth D, Tinnucci JP, Heasley KA, eds. Rock Mechanics in the Public Interest. Proceedings of the 38th U.S. Rock Mechanics Symposium, DC Rocks, Vol. 2 (Washington, DC, July 7-10, 2001). Rotterdam: Balkema, pp.1067-1094.

Wieland MS [2001]. Scaled cloud model for released toxic fumes. In: Proceedings of the 10th Annual High-Tech Blasting Seminar. Allentown, PA: Blasting Analysis International, Inc., pp. $\mathrm{P}-1$ to $\mathrm{P}-18$.

Williams TJ, Denton D, Seymour JB, Tesarik D, Peppein C, Bayer D [2001]. Interaction between wall rock closure, cemented backfill load, and reinforced bolt load in an underhand stope at the Lucky Friday Mine. In: Stone D, ed. Minefill 2001: Proceedings of the Seventh International Symposium on Mining with Backfill. Littleton, CO: Society for Mining, Metallurgy, and Exploration, Inc., pp.117-125. 


\section{Book Chapters/Proceedings/Abstracts/Technical Papers}

Wirth O, Cutlip RG [2001]. Animal models for controlling and quantifying voluntary muscle performance of rats using operant conditioning. In: Bittner AC Jr., Champney PC, Morrissey SJ, eds. Proceedings of the 15th Annual Conference of the International Society for Occupational Ergonomics and Safety, Advances in occupational ergonomics and safety, Vol. 4: Amsterdam, the Netherlands, pp.402-409.

Wirth O, Cutlip RG [2001]. A rat model for controlling and quantifying voluntary muscle performance of upper extremities. In: Hans G, Roland M, eds. Proceedings of the International Society of Biomechanics, Zurich, Switzerland, CD-ROM.

Wirth O, Cutlip RG [2001]. A rat model for controlling and quantifying voluntary muscle performance of upper extremities [Abstract]. Med \& Sci in Sports \& Exercise 33(5):S295.

Woebkenberg ML, McCammon CS [2001]. Chapter 18: Direct-reading gas and vapor instruments. In: Air sampling instruments for evaluation of atmospheric contaminants. 9th ed. Cincinnati, OH: American Conference of Governmental Industrial Hygienists, Inc., pp.507-576.

Wu Z-X, Satterfield BE, Fedan JS, Dey RD [2001]. Interleukin-1 $\beta$-induced airway hyperresponsiveness (AHR) in ferrets enhances substance $\mathrm{P}$ (SP) in intrinsic airway neurons [Abstract]. Am J Respir Crit Care Med 163(5):A626.

Young S, Robinson VA, Barger M. Porter DW, Goldsmith R, Frazer DG, Castranova V [2001]. Modified endotoxin response in rats pre-treated with $1 \rightarrow 3-\beta$-glucan (zymosan A) [Abstract]. The Toxicologist 60(1):197.

Zahl EG, Dunford JP, Tesarik DR, Larson MK [2001]. Development of stress measurements and instrument placement techniques for longwall coal. In: Elsworth D, Tinnucci JP, Heasley KA, eds. Rock Mechanics in the Public Interest. Proceedings of the 38th U.S. Rock Mechanics Symposium, DC Rocks, Vol. 1 (Washington, DC, July 7-10, 2001). Rotterdam: Balkema, pp.327-305.

Zang LY, Qiao GL [2001]. Determination of alachlor and its metabolites in rat plasma and urine using solid phase extraction and liquid chromatography/electrospray ionization-mass spectrometry [Abstract]. The Toxicologist 60(1):94.

Zeidler PC, Ye J, Jones W, Baron P, Martinez A, Robinson VA, Castranova V [2001]. Use of size-selected fibers to evaluate the contribution of length versus chemistry in fiber cytotoxicity [Abstract]. The Toxicologist 60(1):198.

Zhang XD, Millecchia LL, Kommineni C, Lewis DM, Siegel PD [2001]. Time course of specific antibody production following topical skin exposure to dry trimellitic anhydride (TMA) powder [Abstract]. The Toxicologist 60(1):174. 


\section{Book Chapters/Proceedings/Abstracts/Technical Papers}

Zhuang Z, Coffey CC, Jensen PA, Campbell DL, Lawrence RB, Myers WR, Colton CE [2001]. Effect of good- and poor-fitting half-mask respirators on protection under actual workplace environments at a steel foundry. In: Book of Abstracts of the American Industrial Hygiene Conference \& Exposition. Fairfax, VA: American Industrial Hygiene Association, p.35.

Zhuang Z, Coffey CC, Nicholson J, Lawrence RB, Qiao G, Campbell DL, Jensen PA [2001]. Evaluation of new strategies for measuring Freon-113 exposure dose to be correlated to quantitative fit factor. In: Book of Abstracts of the American Industrial Hygiene Conference \& Exposition. Fairfax, VA: American Industrial Hygiene Association, p.69.

Zipf K Jr. [2001]. Pillar design to prevent collapse of room-and-pillar mines. Chapter 59. In: Hustrulid H, Bullock R, eds. Underground Mining Methods: Engineering Fundamentals and International Case Studies. Littleton, CO: Society for Mining, Metallurgy, and Exploration, pp.493-511.

Zlochower IA [2001]. Ignition hazard from internally generated $\mathrm{H}_{2}$ in sealed mining equipment. Eng \& Min J 202(7):ona 16K. 


\section{NIOSH NUMBERED PUBLICATIONS}

NIOSH [2001]. Test results of collision warning system for off-highway dump trucks: phase 2. NIOSH Report of Investigations 9654. Pittsburgh, PA: Department of Health and Human Services, Centers for Disease Control and Prevention, National Institute for Occupational Safety and Health, DHHS (NIOSH) Publication No. 2001-100.

NIOSH [2001]. NORA update, November 2000. Cincinnati, OH: Department of Health and Human Services, Centers for Disease Control and Prevention, National Institute for Occupational Safety and Health, DHHS (NIOSH) Publication No. 2001-101.

NIOSH [2001]. Hearing loss publications. Cincinnati, OH: Department of Health and Human Services, Centers for Disease Control and Prevention, National Institute for Occupational Safety and Health, DHHS (NIOSH) Publication No. 2001-102.

NIOSH [2001]. Work-related hearing loss. Cincinnati, OH: Department of Health and Human Services, Centers for Disease Control and Prevention, National Institute for Occupational Safety and Health, DHHS (NIOSH) Publication No. 2001-103.

NIOSH [2001]. General estimates of work-related noises. Cincinnati, OH: Department of Health and Human Services, Centers for Disease Control and Prevention, National Institute for Occupational Safety and Health, DHHS (NIOSH) Publication No. 2001-104.

NIOSH [2001]. Certified equipment list as of September 30, 2000. Morgantown, WV: Department of Health and Human Services, Centers for Disease Control and Prevention, National Institute for Occupational Safety and Health, DHHS (NIOSH) Publication No. 2001-105.

NIOSH [2001]. Mining publication list 1995-2000. Cincinnati, OH: Department of Health and Human Services, Centers for Disease Control and Prevention, National Institute for Occupational Safety and Health, DHHS (NIOSH) Publication No. 2001-106.

NIOSH [2001]. NIOSH hazard review: carbonless copy paper. Cincinnati, OH: Department of Health and Human Services, Centers for Disease Control and Prevention, National Institute for Occupational Safety and Health, DHHS (NIOSH) Publication No. 2001-107. 


\section{NIOSH Numbered Publications}

NIOSH [2001]. NIOSH Alert: preventing injuries and deaths of workers who operate or work near forklifts: revised edition. Cincinnati, OH: U.S. Department of Health and Human Services, Centers for Disease Control and Prevention, National Institute for Occupational Safety and Health, DHHS (NIOSH) Publication No. 2001-109.

NIOSH [2001]. NIOSH hazard review: health effects of occupational exposure to asphalt. Cincinnati, OH: U.S. Department of Health and Human Services, Centers for Disease Control and Prevention, National Institute for Occupational Safety and Health, DHHS (NIOSH) Publication No. 2001-110.

NIOSH [2001]. Simple solutions: ergonomics for farmworkers. Cincinnati, OH: Department of Health and Human Services, Centers for Disease Control and Prevention, National Institute for Occupational Safety and Health, DHHS (NIOSH) Publication No. 2001-111.

NIOSH [2001]. Epidemic intelligence service opportunities at NIOSH. Atlanta, GA: Department of Health and Human Services, Centers for Disease Control and Prevention, National Institute for Occupational Safety and Health, DHHS (NIOSH) Publication No. 2001-112.

NIOSH [2001]. Health hazard evaluations: issues related to occupational exposure to lead 1994-1999. Cincinnati, OH: Department of Health and Human Services, Centers for Disease Control and Prevention, National Institute for Occupational Safety and Health, DHHS (NIOSH) Publication No. 2001-113.

NIOSH [2001]. A compendium of NIOSH mining research 2001. Pittsburgh, PA: Department of Health and Human Services, Centers for Disease Control and Prevention, National Institute for Occupational Safety and Health, DHHS (NIOSH) Publication No. 2001-114.

NIOSH [2001]. Glutaraldehyde occupational hazards in hospitals. Cincinnati, OH: Department of Health and Human Services, Centers for Disease Control and Prevention, National Institute for Occupational Safety and Health, DHHS (NIOSH) Publication No. 2001-115.

NIOSH [2001]. Health hazard evaluations: tuberculosis 1990-1999. Cincinnati, OH: Department of Health and Human Services, Centers for Disease Control and Prevention, National Institute for Occupational Safety and Health, DHHS (NIOSH) Publication No. 2001-116.

NIOSH [2001]. National occupational research agenda for musculoskeletal disorders. Cincinnati, OH: Department of Health and Human Services, Centers for Disease Control and Prevention, National Institute for Occupational Safety and Health, DHHS (NIOSH) Publication No. 2001-117. 


\section{NIOSH Numbered Publications}

NIOSH [2001]. Tracking occupational injuries, illnesses, and hazards: the NIOSH surveillance strategic plan. Cincinnati, OH: Department of Health and Human Services, Centers for Disease Control and Prevention, National Institute for Occupational Safety and Health, DHHS (NIOSH) Publication No. 2001-118.

NIOSH [2001]. Guide to evaluating the effectiveness of strategies for preventing work injuries: how to show whether a safety intervention really works. Cincinnati, OH: Department of Health and Human Services, Centers for Disease Control and Prevention, National Institute for Occupational Safety and Health, DHHS (NIOSH) Publication No. 2001-119.

NIOSH [2001]. A NIOSH look at data from the Bureau of Labor Statistics: worker health by industry and occupation. Cincinnati, OH: Department of Health and Human Services, Centers for Disease Control and Prevention, National Institute for Occupational Safety and Health, DHHS (NIOSH) Publication No. 2001-120.

NIOSH [2001]. NIOSH musculoskeletal documents on CD-ROM: preventing work-related disorders. Cincinnati, OH: Department of Health and Human Services, Centers for Disease Control and Prevention, National Institute for Occupational Safety and Health, DHHS (NIOSH) Publication No. 2001-122.

NIOSH [2001]. Women's safety and health issues at work. Washington, DC: Department of Health and Human Services, Centers for Disease Control and Prevention, National Institute for Occupational Safety and Health, DHHS (NIOSH) Publication No. 2001-123.

NIOSH [2001]. Haulage truck dump site safety: an examination of reported injuries-NIOSH Information Circular (IC) 9454. Pittsburgh, PA: Department of Health and Human Services, Centers for Disease Control and Prevention, National Institute for Occupational Safety and Health, DHHS (NIOSH) Publication No. 2001-124.

NIOSH [2001]. Protecting workers families-a research agenda. Cincinnati, OH: Department of Health and Human Services, Centers for Disease Control and Prevention, National Institute for Occupational Safety and Health, DHHS (NIOSH) Publication No. 2001-125.

NIOSH [2001]. An analysis of serious injuries to dozer operators in the U.S. mining industry-NIOSH Information Circular (IC) 9455. Pittsburgh, PA: Department of Health and Human Services, Centers for Disease Control and Prevention, National Institute for Occupational Safety and Health, DHHS (NIOSH) Publication No. 2001-126.

NIOSH [2001]. Asphalt fume exposures during the manufacture of asphalt roofing products: current practices for reducing exposures. Cincinnati, OH: Department of Health and Human Services, Centers for Disease Control and Prevention, National Institute for Occupational Safety and Health, DHHS (NIOSH) Publication No. 2001-127. 


\section{NIOSH Numbered Publications}

NIOSH [2001]. Building safer highway work zones: measures to prevent worker injuries from vehicles and equipment. Morgantown, WV: Department of Health and Human Services, Centers for Disease Control and Prevention, National Institute for Occupational Safety and Health, DHHS (NIOSH) Publication No. 2001-128.

NIOSH [2001]. Fatal injuries to civilian workers in the United States, 1980-1995 (National Profile). Cincinnati, OH: Department of Health and Human Services, Centers for Disease Control and Prevention, National Institute for Occupational Safety and Health, DHHS (NIOSH) Publication No. 2001-129.

NIOSH [2001]. Fatal injuries to civilian workers in the United States, 1980-1995 (National and State Profiles). Cincinnati, OH: Department of Health and Human Services, Centers for Disease Control and Prevention, National Institute for Occupational Safety and Health, DHHS (NIOSH) Publication No. 2001-129s.

NIOSH [2001]. Fatal unintentional farm injuries among persons less than 20 years old in the United States: geographic profiles. Cincinnati, OH: Department of Health and Human Services, Centers for Disease Control and Prevention, National Institute for Occupational Safety and Health, DHHS (NIOSH) Publication No. 2001-131.

NIOSH [2001]. Programmable electronic mining systems: best practice recommendations (in nine parts) Part 1: 1.0 Introduction-NIOSH Information Circular (IC) 9456. Pittsburgh, PA: Department of Health and Human Services, Centers for Disease Control and Prevention, National Institute for Occupational Safety and Health, DHHS (NIOSH) Publication No. 2001-132.

NIOSH [2001]. Occupational energy research programs. Cincinnati, OH: Department of Health and Human Services, Centers for Disease Control and Prevention, National Institute for Occupational Safety and Health, DHHS (NIOSH) Publication No. 2001-133.

NIOSH [2001]. Miner training simulator: user's guide and scripting language documentation-NIOSH Information Circular (IC) 9457. Pittsburgh, PA: Department of Health and Human Services, Centers for Disease Control and Prevention, National Institute for Occupational Safety and Health, DHHS (NIOSH) Publication No. 2001-136.

NIOSH [2001]. Programmable electronic mining systems: best practice recommendations (in nine parts) Part 2:2.1 System safety -NIOSH Information Circular (IC) 9458. Pittsburgh, PA: Department of Health and Human Services, Centers for Disease Control and Prevention, National Institute for Occupational Safety and Health, DHHS (NIOSH) Publication No. 2001-137. 


\section{NIOSH Numbered Publications}

NIOSH [2001]. Geomechanics of reinforced cemented backfill in an underhand stope at the Lucky Friday Mine, Mullan, Idaho-NIOSH Report of Investigations (RI). Pittsburgh, PA: Department of Health and Human Services, Centers for Disease Control and Prevention, National Institute for Occupational Safety and Health, DHHS (NIOSH) Publication No. 2001-138.

NIOSH [2001]. Certified equipment list as of March 31, 2001. Morgantown, WV: Department of Health and Human Services, Centers for Disease Control and Prevention, National Institute for Occupational Safety and Health, DHHS (NIOSH) Publication No. 2001-139.

NIOSH [2001]. Use of simulation exercises for safety training in the U.S. mining industry-NIOSH Information Circular (IC) 9459. Pittsburgh, PA: Department of Health and Human Services, Centers for Disease Control and Prevention, National Institute for Occupational Safety and Health, DHHS (NIOSH) Publication No. 2001-141.

NIOSH [2001]. HC-31 Dust protection for bag stackers. Cincinnati, OH: Department of Health and Human Services, Centers for Disease Control and Prevention, National Institute for Occupational Safety and Health, DHHS (NIOSH) Publication No. 2001-142.

NIOSH [2001]. HID-12 Traffic hazards to firefighters while working along roadways. Cincinnati, OH: Department of Health and Human Services, Centers for Disease Control and Prevention, National Institute for Occupational Safety and Health, DHHS (NIOSH) Publication No. 2001-143.

NIOSH [2001]. NIOSH pocket guide to chemical hazards and other databases. CD-ROM. Cincinnati, OH: U.S. Department of Health and Human Services, Public Health Service, Centers for Disease Control and Prevention, National Institute for Occupational Safety and Health, DHHS (NIOSH) Publication No. 2001-145.

NIOSH [2001]. HID-13 Hazards associated with using farm tractors to move large bales. Cincinnati, OH: Department of Health and Human Services, Centers for Disease Control and Prevention, National Institute for Occupational Safety and Health, DHHS (NIOSH) Publication No. 2001-146.

NIOSH [2001]. NORA update 2001. Washington, DC: Department of Health and Human Services, Centers for Disease Control and Prevention, National Institute for Occupational Safety and Health, DHHS (NIOSH) Publication No. 2001-147.

NIOSH [2001]. Injuries among farm workers in the United States-1995. Cincinnati, OH: Department of Health and Human Services, Centers for Disease Control and Prevention, National Institute for Occupational Safety and Health, DHHS (NIOSH) Publication No. 2001-153. 


\section{NIOSH Numbered Publications}

NIOSH [2001]. Injuries among youth on farms in the United States-1998. Cincinnati, OH: Department of Health and Human Services, Centers for Disease Control and Prevention, National Institute for Occupational Safety and Health, DHHS (NIOSH) Publication No. 2001-154.

NIOSH [2001]. NIOSH Alert: preventing injuries and deaths from falls during construction and maintenance of telecommunication towers. Cincinnati, OH: Department of Health and Human Services, Centers for Disease Control and Prevention, National Institute for Occupational Safety and Health, DHHS (NIOSH) Publication No. 2001-156.

NIOSH [2001]. Proceedings: best practices in hearing loss prevention (October 28, 1999 Detroit Michigan) Washington, DC: Department of Health and Human Services, Centers for Disease Control and Prevention, National Institute for Occupational Safety and Health, DHHS (NIOSH) Publication No. 2001-157.

NIOSH [2001]. Training occupational safety and health professionals fact sheet. Washington, DC: Department of Health and Human Services, Centers for Disease Control and Prevention, National Institute for Occupational Safety and Health, DHHS (NIOSH) Publication No. 2001-158.

NIOSH [2001]. Programmable electronic mining systems: best practice recommendations (in nine parts) Part 3:2.2 Software safety-NIOSH Information Circular (IC) 9460. Pittsburgh, PA: Department of Health and Human Services, Centers for Disease Control and Prevention, National Institute for Occupational Safety and Health, DHHS (NIOSH) Publication No. 2001-164.

NIOSH [2001]. A compendium of NIOSH mining research-2002. Pittsburgh, PA: U.S. Department of Health and Human Services, Centers for Disease Control and Prevention, National Institute for Occupational Safety and Health, DHHS (NIOSH) Publication No. 2002-110.

NIOSH [2001]. HID-14 Fire fighter deaths from tanker truck rollovers. Cincinnati, OH: Department of Health and Human Services, Centers for Disease Control and Prevention, National Institute for Occupational Safety and Health, DHHS (NIOSH) Publication No. 2002-111. 


\section{ELECTRONIC AND MEDIA PRODUCTS}

Bowman JD, Gailey PC, Gillette L, Lotz WG, Overton D [2001]. Proceedings of a joint NIOSH/DOE workshop on "EMF Exposure Assessment and Epidemiology: Hypotheses, Metrics, and Measurements." Cincinnati, OH: U.S. Department of Health and Human Services, Public Health Service, Centers for Disease Control and Prevention, National Institute for Occupational Safety and Health. [http://www.cdc.gov/niosh/emfpg.htmlworkshop]. Date accessed: 2001.

Cecala AB, Organiscak JA, Urban CW [2001]. Reducing dust inside enclosed cabs. Pittsburgh, PA: U.S. Department of Health and Human Services, Public Health Service, Centers for Disease Control and Prevention, National Institute for Occupational Safety and Health. Videocassette.

Hudock SD, Chrislip DW [2001]. Ergonomics solutions in shipyards/reports. Cincinnati, OH: U.S. Department of Health and Human Services, Public Health Service, Centers for Disease Control and Prevention, National Institute for Occupational Safety and Health.

[http://www.cdc.gov/niosh/ergship/reports.html]. Date accessed: 2001.

Li F, Huston RL, Waters TR [2001]. Musculoskeletal dynamics of heavy equipment operators. In: Proceedings of the International Conference on Computer-Aided Ergonomics and Safety, Maui, HI: International Ergonomics Association. CD-ROM.

Mallett LG, Brnich MJ, Vaught C, Reinke D, Urban CW, Lenart PJ [2001]. Care and maintenance of the SR-100 self-contained self-rescuer. Pittsburgh, PA: U.S. Department of Health and Human Services, Public Health Service, Centers for Disease Control and Prevention, National Institute for Occupational Safety and Health. Videocassette.

McHugh EL, Girard JM, Denes LJ [2001]. Simplified hyperspectral imaging for improved geologic mapping of mine slopes. In: Meech JA, Veiga SM, Viega MM, LeClair SR, Maguire JF, eds. Proceedings of the Third International Conference on Intelligent Processing and Manufacturing of Materials (Vancouver, BC, July 29-Aug 2). CD-ROM.

NIOSH [2001]. Emergency response resources. Cincinnati, OH: U.S. Department of Health and Human Services, Centers for Disease Control and Prevention, National Institute for Occupational Safety and Health. [http://www.cdc.gov/niosh/emres01.html]. Date accessed: 2001.

NIOSH [2001]. Eye safety: emergency response and disaster recovery. Morgantown, WV: Department of Health and Human Services, Centers for Disease Control and Prevention, National Institute for Occupational Safety and Health. [http://www.cdc.gov/niosh/eyesafe.html]. Date accessed: 2001. 


\section{Electronic and Media Products}

NIOSH [2001]. Hazards in motion. Spokane, WA: U.S. Department of Health and Human Services, Public Health Service, Centers for Disease Control and Prevention, National Institute for Occupational Safety and Health. Videocassette.

NIOSH [2001]. Hidden scars. Spokane, WA: U.S. Department of Health and Human Services, Public Health Service, Centers for Disease Control and Prevention, National Institute for Occupational Safety and Health. Videocassette.

NIOSH [2001]. Needlestick injury: a nurse's story. Cincinnati, OH: U.S. Department of Health and Human Services, Public Health Service, Centers for Disease Control and Prevention, National Institute for Occupational Safety and Health. Videocassette.

NIOSH [2001]. NIOSH pocket guide to chemical hazards and other databases. CD-ROM. Cincinnati, OH: U.S. Department of Health and Human Services, Public Health Service, Centers for Disease Control and Prevention, National Institute for Occupational Safety and Health, DHHS (NIOSH) Publication No. 2001-145.

NIOSH [2001]. Recovery of Farmington No. 9: an interview with Danny Kuhn. Pittsburgh, PA: U.S. Department of Health and Human Services, Public Health Service, Centers for Disease Control and Prevention, National Institute for Occupational Safety and Health. Videocassette.

NIOSH [2001]. TB respiratory protection: administrator's review. Cincinnati, OH: U.S. Department of Health and Human Services, Public Health Service, Centers for Disease Control and Prevention, National Institute for Occupational Safety and Health. Videocassette.

Sauter SL, Chrislip DW [2001]. Stress...at work. Cincinnati, OH: U.S. Department of Health and Human Services, Public Health Service, Centers for Disease Control and Prevention, National Institute for Occupational Safety and Health. [http://www.cdc.gov/niosh/stresshp.html]. Date accessed: 2001.

Scharf T [2001]. A practical approach to evaluating the effectiveness of workplace health and safety interventions. Fairfax, VA: American Industrial Hygiene Association. [http://www.aiha.org/aihce01/handouts/fm321scharf.htm]. Date accessed: 2001.

Tatken RL, Gjessing CC, Morgan VK, eds. [2001]. NIOSH musculoskeletal documents on CD-ROM: preventing work-related disorders. CD-ROM. 


\section{HAZARD EVALUATION AND TECHNICAL ASSISTANCE REPORTS}

Boudreau Y, Weber A [2001]. Hazard Evaluation and Technical Assistance Report: Dallas Institute of Acupuncture and Oriental Medicine, Dallas, TX. Cincinnati, OH: U.S. Department of Health and Human Services, Public Health Service, Centers for Disease Control and Prevention, National Institute for Occupational Safety and Health, NIOSH Report No. HETA 2000-0341-2839.

Burton NC [2001]. Hazard Evaluation and Technical Assistance Report: State of Iowa Division of Narcotics Enforcement, Des Moines, IA. Cincinnati, OH: U.S. Department of Health and Human Services, Public Health Service, Centers for Disease Control and Prevention, National Institute for Occupational Safety and Health, NIOSH Report No. HETA 99-0252-2831.

Burton NC, Martinez, KF [2001]. Hazard Evaluation and Technical Assistance Report: Group Health Associates, Cincinnati, OH. Cincinnati, OH: U.S. Department of Health and Human Services, Public Health Service, Centers for Disease Control and Prevention, National Institute for Occupational Safety and Health, NIOSH Report No. HETA 2000-0339-2852.

Cocalis J, Rao C, Kestenberg K, Martin J [2001]. Hazard evaluation and technical assistance report: Robinson Run Mine, Shinnston, WV. Morgantown, WV: U.S. Department of Health and Human Services, Public Health Service, Centers for Disease Control and Prevention, National Institute for Occupational Safety and Health, NIOSH Report No. HETA 2000-0098-2862.

Cook CK, Hess JE, Tubbs R [2001]. Hazard Evaluation and Technical Assistance Report: Wire Rope Corp. of America, Sedalia, MO. Cincinnati, OH: U.S. Department of Health and Human Services, Public Health Service, Centers for Disease Control and Prevention, National Institute for Occupational Safety and Health, NIOSH Report No. HETA 2001-0181-2841.

Cook CK, Malkin R [2001]. Hazard Evaluation and Technical Assistance Report: Riverside County Regional Medical Center, Danbury, WI. Cincinnati, OH: U.S. Department of Health and Human Services, Public Health Service, Centers for Disease Control and Prevention, National Institute for Occupational Safety and Health, NIOSH Report No. HETA 2000-0169-2854.

Delaney LJ [2001]. Hazard Evaluation and Technical Assistance Report: Saint Croix Tribe of Chippewa Indians Aquaculture Facility, Danbury, WI. Cincinnati, OH: U.S. Department of

Health and Human Services, Public Health Service, Centers for Disease Control and Prevention, National Institute for Occupational Safety and Health, NIOSH Report No. HETA 2001-0189-2842. 


\section{Hazard Evaluation and Technical Assistance Reports}

Gwin KK [2001]. Hazard Evaluation and Technical Assistance Report: Pappas Chiropractic Center, Piscataway, NJ. Cincinnati, OH: U.S. Department of Health and Human Services, Public Health Service, Centers for Disease Control and Prevention, National Institute for Occupational Safety and Health, NIOSH Report No. HETA 2000-0363-2834.

Gwin KK, Feldman DM [2001]. Hazard Evaluation and Technical Assistance Report: Boat America Corporation, Alexandria, VA. Cincinnati, OH: U.S. Department of Health and Human Services, Public Health Service, Centers for Disease Control and Prevention, National Institute for Occupational Safety and Health, NIOSH Report No. HETA 2001-0059-2861.

Gwin KK, Wallingford KM, Morata TC, Campen LE Van [2001]. Hazard Evaluation and Technical Assistance Report: Human Performance International, Inc., Charlotte, NC. Cincinnati, OH: U.S. Department of Health and Human Services, Public Health Service, Centers for Disease Control and Prevention, National Institute for Occupational Safety and Health, NIOSH Report No. HETA 2000-0110-2849.

Habes DJ, Dick RB, Tubbs RL, Biggs FR, Burt SE [2001]. Hazard Evaluation and Technical Assistance Report: Yellowstone National Park, Yellowstone National Park, WY. Cincinnati, OH: U.S. Department of Health and Human Services, Public Health Service, Centers for Disease Control and Prevention, National Institute for Occupational Safety and Health, NIOSH Report No. HETA 99-0283-2855

Hales T, Baldwin T [2001]. Hazard Evaluation and Technical Assistance Report: Madison Fire Department, Madison, WI. Cincinnati, OH: U.S. Department of Health and Human Services, Public Health Service, Centers for Disease Control and Prevention, National Institute for Occupational Safety and Health, NIOSH Report No. HETA 2001-0043-2844.

Hall RM, Gwin KK [2001]. Hazard Evaluation and Technical Assistance Report: Lehigh Portland Cement Company, Union Bridges, MD. Cincinnati, OH: U.S. Department of Health and Human Services, Public Health Service, Centers for Disease Control and Prevention, National Institute for Occupational Safety and Health, NIOSH, HETA Report No. 2000-0098-2857.

Hall RM, Martinez KF, Page EL [2001]. Hazard Evaluation and Technical Assistance Report: Rehabilitation Services Commission, Columbus, OH. Cincinnati, OH: U.S. Department of Health and Human Services, Public Health Service, Centers for Disease Control and Prevention, National Institute for Occupational Safety and Health, NIOSH Report No. HETA 2000-0283-2823.

Harney JM, Trout D [2001]. Hazard Evaluation and Technical Assistance Report: Southern Supply \& Manufacturing Company, Inc., St. Petersburg, FL. Cincinnati, OH: U.S. Department of Health and Human Services, Public Health Service, Centers for Disease Control and Prevention, National Institute for Occupational Safety and Health, NIOSH Report No. HETA 2000-0262-2833. 


\section{Hazard Evaluation and Technical Assistance Reports}

Hewett P, Kestenberg K [2001]. Hazard evaluation and technical assistance report: SFO International Terminal, San Francisco, CA. Morgantown, WV: U.S. Department of Health and Human Services, Public Health Service, Centers for Disease Control and Prevention, National Institute for Occupational Safety and Health, NIOSH Report No. HETA 2000-0134-2847.

Hnizdo E, Kullman G, Gao P [2001]. Hazard evaluation and technical assistance report: North View Elementary School, Clarksburg, WV. Morgantown, WV: U.S. Department of Health and Human Services, Public Health Service, Centers for Disease Control and Prevention, National Institute for Occupational Safety and Health, NIOSH Report No. HETA 99-0235-2836.

Kasting C, McCullough J, Kiefer M [2001]. Hazard Evaluation and Technical Assistance Report: U.S. Airways/Charlotte Aircraft Support Center, Charlotte, NC. Cincinnati, OH: U.S.

Department of Health and Human Services, Public Health Service, Centers for Disease Control and Prevention, National Institute for Occupational Safety and Health, NIOSH Report No.

HETA 99-0342-2821.

Kiefer M [2001] Hazard Evaluation and Technical Assistance Report: MD Anderson Cancer Center, Houston, TX. Cincinnati, OH :U.S. Department of Health and Human Services, Public Health Service, Centers for Disease Control and Prevention, National Institute for Occupational Safety and Health, NIOSH Report No. HETA 98-0052-2820.

Kiefer M, Delaney L [2001]. Hazard Evaluation and Technical Assistance Report: Lac Vieux Desert Resort and Casino, Watersmeet, MI. Cincinnati, OH: U.S. Department of Health and Human Services, Public Health Service, Centers for Disease Control and Prevention, National Institute for Occupational Safety and Health, NIOSH Report No. HETA 2001-0109-2835.

Kiefer M, Weber A [2001]. Hazard Evaluation and Technical Assistance Report: US Airways Aircraft Support Center, Charlotte, NC. Cincinnati, OH: U.S. Department of Health and Human Services, Public Health Service, Centers for Disease Control and Prevention, National Institute for Occupational Safety and Health, NIOSH Report No. HETA 2001-0034-2843.

King BS, Hess JE [2001]. Hazard Evaluation and Technical Assistance Report: Winnebago Industries, Inc., Forest City, IA. Cincinnati, OH: U.S. Department of Health and Human Services, Public Health Service, Centers for Disease Control and Prevention, National Institute for Occupational Safety and Health, NIOSH Report No. HETA 2000-0250-2837.

King B, Hess JE [2001]. Hazard Evaluation and Technical Assistance Report: Ogden Aviation Services, St. Louis, MO. Cincinnati, OH: U.S. Department of Health and Human Services, Public Health Service, Centers for Disease Control and Prevention, National Institute for Occupational Safety and Health, NIOSH Report No. HETA 2000-0423-2858. 


\section{Hazard Evaluation and Technical Assistance Reports}

Lee SA [2001]. Hazard Evaluation and Technical Assistance Report: U.S. Park Service, Cheney, WA. Cincinnati, OH: U.S. Department of Health and Human Services, Public Health Service, Centers for Disease Control and Prevention, National Institute for Occupational Safety and Health, NIOSH Report No. HETA 99-0173-2856.

Malkin R [2001]. Hazard Evaluation and Technical Assistance Report: Indian Health Service, Rockville, MD. Cincinnati, OH: U.S. Department of Health and Human Services, Public Health Service, Centers for Disease Control and Prevention, National Institute for Occupational Safety and Health, NIOSH Report No. HETA 99-0106-2838.

McCleery RE, Blade LM, Burt SE [2001]. Health hazard evaluation report at Special Metals Corporation, Princeton Powder Division, Princeton, KY. Cincinnati, OH: U.S. Department of Health and Human Services, Public Health Service, Centers for Disease Control and Prevention, National Institute for Occupational Safety and Health, NIOSH Report No. HETA 97-0141-2819.

McCleery RE, Burr GA, Martinez KF [2001]. Hazard Evaluation and Technical Assistance Report: Charles Harwood Complex, Saint Croix, United States, Virgin Islands. Cincinnati, OH: U.S. Department of Health and Human Services, Public Health Service, Centers for Disease Control and Prevention, National Institute for Occupational Safety and Health, NIOSH Report No. HETA 2000-0092-2832.

McCleery RE, McCullough J, Hall RM, Fernback JE [2001]. Hazard Evaluation and Technical Assistance Report: Cellulose Insulation Applicators: U.S. Department of Health and Human Services, Public Health Service, Centers for Disease Control and Prevention, National Institute for Occupational Safety and Health, NIOSH Report No. HETA 2000-0332-2827.

Page E, Harney JM [2001]. Hazard Evaluation and Technical Assistance Report: United Catalysts, Inc., Louisville, KY. Cincinnati, OH: U.S. Department of Health and Human Services, Public Health Service, Centers for Disease Control and Prevention, National Institute for Occupational Safety and Health, NIOSH Report No. HETA 2000-0139-2824.

Piacitelli C, Filios M [2001]. Hazard Evaluation and Technical Assistance Report: CSX Transportation, Inc., Nashville, TN. Cincinnati, OH: U.S. Department of Health and Human Services, Public Health Service, Centers for Disease Control and Prevention, National Institute for Occupational Safety and Health, NIOSH Report No. HETA 92-0311-2826.

Reh BD, Page E, Harney J, McCleery RE [2001]. Hazard Evaluation and Technical Assistance Report: Campbell Hausfeld, Harrison, OH. Cincinnati, OH: U.S. Department of Health and Human Services, Public Health Service, Centers for Disease Control and Prevention, National Institute for Occupational Safety and Health, NIOSH Report No. HETA 2000-0356-2851. 


\section{Hazard Evaluation and Technical Assistance Reports}

Reh CM, Nemhauser JB [2001]. Hazard Evaluation and Technical Assistance Report: Trilithic, Inc., Indianapolis, IN. Cincinnati, OH: U.S. Department of Health and Human Services, Public Health Service, Centers for Disease Control and Prevention, National Institute for Occupational Safety and Health, NIOSH Report No. HETA 2000-0233-2845.

Roegner K, Tapp L, McCleery R [2001]. Hazard Evaluation and Technical Assistance Report: E.I. DuPont de Nemours and Co., Inc., Richmond, VA. Cincinnati, OH: U.S. Department of Health and Human Services, Public Health Service, Centers for Disease Control and Prevention, National Institute for Occupational Safety and Health, NIOSH Report No. HETA 2000-0291-2840.

Roegner KC, Sieber WK, Echt A [2001]. Hazard Evaluation and Technical Assistance Report: Costa Mesa Fire Department, Costa Mesa, CA. Cincinnati, OH: U.S. Department of Health and Human Services, Public Health Service, Centers for Disease Control and Prevention, National Institute for Occupational Safety and Health, NIOSH Report No. HETA 99-0266-2850.

Roegner KC, Tapp L, Martinez KR, Trout D, Mueller C [2001]. Hazard Evaluation and Technical Assistance Report: Boeing Commercial Airplane Group, Oak Ridge, TN. Cincinnati, OH: U.S. Department of Health and Human Services, Public Health Service, Centers for Disease Control and Prevention, National Institute for Occupational Safety and Health, NIOSH Report No. HETA 99-0177-2828.

Schrader SM, Breitenstein MJ, Lowe BD [2001]. Hazard Evaluation and Technical Assistance Report: Long Beach Police Department, Long Beach, CA. Cincinnati, OH: U.S. Department of Health and Human Services, Public Health Service, Centers for Disease Control and Prevention, National Institute for Occupational Safety and Health, NIOSH Report No. HETA 2000-0305-2848.

Seitz T, Malkin R, Jekabzone I [2001]. Hazard Evaluation and Technical Assistance Report: The Centre for Well-Being at The Phoenician, Scottsdale, AZ. Cincinnati, OH: U.S. Department of Health and Human Services, Public Health Service, Centers for Disease Control and Prevention, National Institute for Occupational Safety and Health, NIOSH Report No. HETA 2000-0176-2829.

Sussell AL, Piacitelli GM [2001]. Hazard Evaluation and Technical Assistance Report: University of California, Berkeley, CA. Cincinnati, OH: U.S. Department of Health and Human Services, Public Health Service, Centers for Disease Control and Prevention, National Institute for Occupational Safety and Health, NIOSH Report No. HETA 99-0113-2853.

Tepper A, Mueller C, Hurrell JJ, Kang D [2001]. Hazard Evaluation and Technical Assistance Report: Anaheim Fire Department, Anaheim, CA. Cincinnati, OH: U.S. Department of Health and Human Services, Public Health Service, Centers for Disease Control and Prevention, National Institute for Occupational Safety and Health, NIOSH Report No. HETA 94-0390-2822. 
Tubbs RL [2001]. Hazard Evaluation and Technical Assistance Report: Oklahoma City Community College, Oklahoma City, OK. Cincinnati, OH: U.S. Department of Health and Human Services, Public Health Service, Centers for Disease Control and Prevention, National Institute for Occupational Safety and Health, NIOSH Report No. HETA 2001-0496-2866.

Weber AM [2001]. Hazard Evaluation and Technical Assistance Report: Body Piercing by Bink, Tallahassee, FL. Cincinnati, OH: U.S. Department of Health and Human Services, Public Health Service, Centers for Disease Control and Prevention, National Institute for Occupational Safety and Health, NIOSH Report No. HETA 2000-0013-2830.

Weber AM [2001]. Hazard Evaluation and Technical Assistance Report: Venus \& Mars, Orlando, FL. Cincinnati, OH: U.S. Department of Health and Human Services, Public Health Service, Centers for Disease Control and Prevention, National Institute for Occupational Safety and Health, NIOSH Report No. HETA 99-0265-2830. 


\section{FATALITY ASSESSMENT AND CONTROL EVALUATIONS}

NIOSH [2001]. Fourteen-year-old laborer dies after a stored piece of hoisting apparatus fell on him at an automobile repossession yard-Pennsylvania. Morgantown, WV: National Institute for Occupational Safety and Health, Division of Safety Research, FACE Report No. 2000-04.

NIOSH [2001]. A sixteen-year-old male died after falling 27 feet at a residential construction site-Alabama. Morgantown, WV: National Institute for Occupational Safety and Health, Division of Safety Research, FACE Report No. 2000-16.

NIOSH [2001]. Twenty-nine-year-old asphalt compactor operator dies from crushing injuries received during machine rollover-North Carolina. Morgantown, WV: National Institute for Occupational Safety and Health, Division of Safety Research, FACE Report No. 2000-20.

NIOSH [2001]. Fourteen-year-old youth pulled into operating wood chipper-Florida. Morgantown, WV: National Institute for Occupational Safety and Health, Division of Safety Research, FACE Report No. 2000-21.

NIOSH [2001]. Seventeen-year-old laborer at salvage lumber operation crushed by forklift that tipped over-New York. Morgantown, WV: National Institute for Occupational Safety and Health, Division of Safety Research, FACE Report No. 2000-22.

NIOSH [2001]. State Department of Transportation worker (laborer) dies after being struck by motor vehicle. Morgantown, WV: National Institute for Occupational Safety and Health, Division of Safety Research, FACE Report No. 2001-01.

NIOSH [2001]. State Department of Transportation highway maintenance worker dies after being struck by a car while installing reflectors on a guardrail. Morgantown, WV: National Institute for Occupational Safety and Health, Division of Safety Research, FACE Report No. 2001-02.

NIOSH [2001]. Thirty-eight-year-old stevedore at river port materials handling facility struck by collapsing crane boom-Arkansas. Morgantown, WV: National Institute for Occupational Safety and Health, Division of Safety Research, FACE Report No. 2001-03.

NIOSH [2001]. Seventeen-year-old bagger at a retail grocery store suffers amputation while operating a meat grinder-Pennsylvania. Morgantown, WV: National Institute for Occupational Safety and Health, Division of Safety Research, FACE Report No. 2001-05. 


\section{Fatality Assessment and Control Evaluations}

NIOSH [2001]. Eighteen-year-old sporting goods retail store worker dies in a fall from a shelving unit-Pennsylvania. Morgantown, WV: National Institute for Occupational Safety and Health, Division of Safety Research, FACE Report No. 2001-06.

NIOSH [2001]. Seventeen-year-old part-time road construction laborer dies after being run over by a water truck-Indiana. Morgantown, WV: National Institute for Occupational Safety and Health, Division of Safety Research, FACE Report No. 2001-10.

\section{Fire Fighter - Fatality Assessment and Control Evaluation}

NIOSH [2001]. Electrical panel explosion claims the life of a career assistant fire chief, an electrician, and seriously injures an assistant building engineer-Illinois. Morgantown, WV: National Institute for Occupational Safety and Health, Division of Safety Research, Fire Fighter Fatality Investigation and Prevention Program Report No. 99F-28.

NIOSH [2001]. Structure fire claims the lives of three career fire fighters and three childrenIowa. Morgantown, WV: National Institute for Occupational Safety and Health, Division of Safety Research, Fire Fighter Fatality Investigation and Prevention Program Report No. F2000-04.

NIOSH [2001]. Restaurant fire claims the life of two career fire fighters-Texas. Morgantown, WV: National Institute for Occupational Safety and Health, Division of Safety Research, Fire Fighter Fatality Investigation and Prevention Program Report No. F2000-13.

NIOSH [2001]. Battalion chief suffers a heart attack and eventually dies while participating in a fitness program-California. Cincinnati, OH: National Institute for Occupational Safety and Health, Division of Safety Research, Fire Fighter Fatality Investigation and Prevention Program Report No. F2000-15.

NIOSH [2001]. A volunteer fire fighter/driver was killed and another volunteer fire fighter was injured while responding to a motor vehicle incident with injuries-California. Morgantown, WV: National Institute for Occupational Safety and Health, Division of Safety Research, Fire Fighter Fatality Investigation and Prevention Program Report No. F2000-17.

NIOSH [2001]. A volunteer fire fighter died and a second was seriously injured after fuel tank explosion-Iowa. Morgantown, WV: National Institute for Occupational Safety and Health, Division of Safety Research, Fire Fighter Fatality Investigation and Prevention Program Report No. F2000-25.

NIOSH [2001]. Residential structure fire claims the life of one career fire fighter-Alabama. Morgantown, WV: National Institute for Occupational Safety and Health, Division of Safety Research, Fire Fighter Fatality Investigation and Prevention Program Report No. F2000-26. 


\section{Fatality Assessment and Control Evaluations}

NIOSH [2001]. Volunteer assistant chief dies during a controlled-burn training evolutionDelaware. Morgantown, WV: National Institute for Occupational Safety and Health, Division of Safety Research, Fire Fighter Fatality Investigation and Prevention Program Report No. F2000-27.

NIOSH [2001]. Junior fire fighter killed responding to call in his privately owned vehicle (POV)-Pennsylvania. Morgantown, WV: National Institute for Occupational Safety and Health, Division of Safety Research, Fire Fighter Fatality Investigation and Prevention Program Report No. F2000-35.

NIOSH [2001]. Captain suffers a heart attack at a structure fire and dies 12 days later-Illinois. Cincinnati, OH: National Institute for Occupational Safety and Health, Division of Safety Research, Fire Fighter Fatality Investigation and Prevention Program Report No. F2000-36.

NIOSH [2001]. Arson investigator dies from injuries sustained from a fall during an arson investigation-Illinois. Morgantown, WV: National Institute for Occupational Safety and Health, Division of Safety Research, Fire Fighter Fatality Investigation and Prevention Program Report No. F2000-37.

NIOSH [2001]. Fire fighter/SCUBA diver dies during training evolution-Indiana. Morgantown, WV: National Institute for Occupational Safety and Health, Division of Safety Research, Fire Fighter Fatality Investigation and Prevention Program Report No. F2000-38.

NIOSH [2001]. A lieutenant dies and three fire fighters of a career department were injured when the truck they were responding in was struck by another vehicle-Illinois. Morgantown, WV: National Institute for Occupational Safety and Health, Division of Safety Research, Fire Fighter Fatality Investigation and Prevention Program Report No. F2000-39.

NIOSH [2001]. Fire fighter dies after being run over by ladder truck while attempting to boardAlabama. Morgantown, WV: National Institute for Occupational Safety and Health, Division of Safety Research, Fire Fighter Fatality Investigation and Prevention Program Report No. F2000-41.

NIOSH [2001]. A volunteer assistant chief was seriously injured and two volunteer fire fighters were injured while fighting a townhouse fire-Delaware. Morgantown, WV: National Institute for Occupational Safety and Health, Division of Safety Research, Fire Fighter Fatality Investigation and Prevention Program Report No. F2000-43.

NIOSH [2001]. Roof collapse injures four career fire fighters at a church fire-Arkansas. Morgantown, WV: National Institute for Occupational Safety and Health, Division of Safety Research, Fire Fighter Fatality Investigation and Prevention Program Report No. F2001-03. 


\section{Fatality Assessment and Control Evaluations}

NIOSH [2001]. Volunteer fire fighter (lieutenant) killed and one fire fighter injured during mobile home fire-Pennsylvania. Morgantown, WV: National Institute for Occupational Safety and Health, Division of Safety Research, Fire Fighter Fatality Investigation and Prevention Program Report No. F2001-04.

NIOSH [2001]. Driver/operator dies at his station after responding to three emergency incidentsMassachusetts. Morgantown, WV: National Institute for Occupational Safety and Health, Division of Safety Research, Fire Fighter Fatality Investigation and Prevention Program Report No. F2001-05.

NIOSH [2001]. Volunteer fire fighter dies and another fire fighter is injured during wall collapse at fire at local business-Wisconsin. Morgantown, WV: National Institute for Occupational Safety and Health, Division of Safety Research, Fire Fighter Fatality Investigation and Prevention Program Report No. F2001-09.

NIOSH [2001]. Driver/operator suffers a cardiac arrest during a wildland fire exercise-Georgia. Cincinnati, OH: National Institute for Occupational Safety and Health, Division of Safety Research, Fire Fighter Fatality Investigation and Prevention Program Report No. F2001-11.

NIOSH [2001]. Residential fire claims the lives of two volunteer fire fighters and seriously injures an assistant chief-Missouri. Morgantown, WV: National Institute for Occupational Safety and Health, Division of Safety Research, Fire Fighter Fatality Investigation and Prevention Program Report No. F2001-15.

NIOSH [2001]. Motor-vehicle incident claims the life of a volunteer assistant chief-Alaska. Morgantown, WV: National Institute for Occupational Safety and Health, Division of Safety Research, Fire Fighter Fatality Investigation and Prevention Program Report No. F2001-17.

NIOSH [2001]. Fire fighter dies after assisting an injured person-Ohio. Morgantown, WV: National Institute for Occupational Safety and Health, Division of Safety Research, Fire Fighter Fatality Investigation and Prevention Program Report No. F2001-19.

NIOSH [2001]. Fire fighter has sudden cardiac death during training-Texas. Cincinnati, OH: National Institute for Occupational Safety and Health, Division of Safety Research, Fire Fighter Fatality Investigation and Prevention Program Report No. F2001-20.

NIOSH [2001]. Fire fighter dies in sleep during his work shift-Michigan. Cincinnati, OH: National Institute for Occupational Safety and Health, Division of Safety Research, Fire Fighter Fatality Investigation and Prevention Program Report No. F2001-21.

NIOSH [2001]. Fire fighter dies while on duty-Texas. Cincinnati, OH: National Institute for Occupational Safety and Health, Division of Safety Research, Fire Fighter Fatality Investigation and Prevention Program Report No. F2001-22. 
NIOSH [2001]. Fire fighter suffers sudden cardiac death while exercising during his shiftCalifornia. Cincinnati, OH: National Institute for Occupational Safety and Health, Division of Safety Research, Fire Fighter Fatality Investigation and Prevention Program Report No.

F2001-24.

NIOSH [2001]. Fire fighter dies after completing job task evaluation-Alabama. Cincinnati, OH: National Institute for Occupational Safety and Health, Division of Safety Research, Fire Fighter Fatality Investigation and Prevention Program Report No. F2001-25. 


\section{TECHNOLOGY NEWS}

NIOSH [2001]. Technology news 484: Devices to monitor blind spots near large haulage equipment. Pittsburgh, PA: U.S. Department of Health and Human Services, Public Health Service, Centers for Disease Control and Prevention, National Institute for Occupational Safety and Health.

NIOSH [2001]. Technology news 485: Improved cab air inlet location reduces dust levels and air filter loading rates. Pittsburgh, PA: U.S. Department of Health and Human Services, Public Health Service, Centers for Disease Control and Prevention, National Institute for Occupational Safety and Health.

NIOSH [2001]. Technology news 486: Floor heaters can increase operator's dust exposure in enclosed cabs. Pittsburgh, PA: U.S. Department of Health and Human Services, Public Health Service, Centers for Disease Control and Prevention, National Institute for Occupational Safety and Health.

NIOSH [2001]. Technology news 487: Sweeping compound application reduces dust from soiled floors within enclosed operator cabs. Pittsburgh, PA: U.S. Department of Health and Human Services, Public Health Service, Centers for Disease Control and Prevention, National Institute for Occupational Safety and Health.

NIOSH [2001]. Technology news 488: Migration of blasting fumes into a western Pennsylvania home. Pittsburgh, PA: U.S. Department of Health and Human Services, Public Health Service, Centers for Disease Control and Prevention, National Institute for Occupational Safety and Health.

NIOSH [2001]. Technology news 489: Reducing the danger of explosions in sealed areas (gobs) in mines. Pittsburgh, PA: U.S. Department of Health and Human Services, Public Health Service, Centers for Disease Control and Prevention, National Institute for Occupational Safety and Health.

NIOSH [2001]. Technology news 490: An inexpensive device for monitoring explosions in sealed areas of underground mines. Pittsburgh, PA: U.S. Department of Health and Human Services, Public Health Service, Centers for Disease Control and Prevention, National Institute for Occupational Safety and Health.

NIOSH [2001]. Technology news 491: NIOSH releases two new safety training videos. Spokane, WA: U.S. Department of Health and Human Services, Public Health Service, Centers for Disease Control and Prevention, National Institute for Occupational Safety and Health. 
NIOSH [2001]. Technology news 492: Proceedings of the Second International Workshop on Coal Pillar Mechanics and Design, Information Circular (IC) 9448. Pittsburgh, PA: U.S. Department of Health and Human Services, Public Health Service, Centers for Disease Control and Prevention, National Institute for Occupational Safety and Health.

NIOSH [2001]. Technology news 493: Proceedings - New Technology for Coal Mine Roof Support, Information Circular (IC) 9453. Pittsburgh, PA: U.S. Department of Health and Human Services, Public Health Service, Centers for Disease Control and Prevention, National Institute for Occupational Safety and Health. 


\section{CONTROL TECHNOLOGY REPORTS}

Almaguer DA, Shulman SA, Echt AS [2001]. In-depth survey report: control technology for ready-mix truck drum cleaning at Hilltop Basic Resources, Cincinnati, Ohio, January 14-February 12, 1999. Cincinnati, OH: U.S. Department of Health and Human Services, Public Health Service, Centers for Disease Control and Prevention, National Institute for Occupational Safety and Health.

Dunn KH, Earnest GS [2001]. Survey report: options for the control of border agents exposure to vehicle emissions: recommendations for a pilot study at United States Port of Entry, Calexico, California, November 15-17, 2000. Cincinnati, OH: U.S. Department of Health and Human Services, Public Health Service, Centers for Disease Control and Prevention, National Institute for Occupational Safety and Health.

Dunn KH, Hall RM, McCammon JB, Earnest GS [2001]. In-depth survey report: an evaluation of an engineering control to prevent carbon monoxide poisonings of individuals on houseboats at Sumerset Custom Houseboats, Somerset, Kentucky, March 1, 2001. Cincinnati, OH: U.S. Department of Health and Human Services, Public Health Service, Centers for Disease Control and Prevention, National Institute for Occupational Safety and Health.

Earnest GS, Dunn KH, Hall RM, McCammon JB, McCleery RE, Jones A [2001]. In-depth survey report: an evaluation of an emission control device, exhaust stack, and interlock to prevent carbon monoxide poisonings of individuals on houseboats at Callville Bay Marina, Boulder City, Nevada, June 18-21, 2001. Cincinnati, OH: U.S. Department of Health and Human Services, Public Health Service, Centers for Disease Control and Prevention, National Institute for Occupational Safety and Health.

Earnest GS, Dunn KH, Hall RM, McCleery RE, McCammon JB [2001]. An evaluation of an engineering control to prevent carbon monoxide poisonings of individuals on houseboats at Wahweap Marina, Lake Powell, Arizona, February 6-8, 2001. Cincinnati, OH: U.S. Department of Health and Human Services, Public Health Service, Centers for Disease Control and Prevention, National Institute for Occupational Safety and Health.

Echt AS [2001]. In-depth survey report of four sites: exposure to silica from hand tools in construction chipping, grinding, and hand demolition at Frank Messer and Sons Construction Company, Lexington and Newport, Kentucky, and Columbus and Springfield, Ohio, May 26, 30, and 31, July 6, September 11 and 26, 2000. Cincinnati, OH: U.S. Department of Health and Human Services, Public Health Service, Centers for Disease Control and Prevention, National Institute for Occupational Safety and Health. 
VIII. Control Technology Reports

Gressel MG, Shulman SA [2001]. Comparison of mist generation of micro-lubrication and flood application of metalworking fluids during machining. Cincinnati, OH: U.S. Department of Health and Human Services, Public Health Service, Centers for Disease Control and Prevention, National Institute for Occupational Safety and Health.

Heitbrink WA, Moyer ES [2001]. In-depth survey report: control technology for environmental enclosures - an evaluation of in-use enclosures at John Deere Product Engineering Center, Waterloo, Iowa, April 18-19, 2001. Cincinnati, OH: U.S. Department of Health and Human Services, Public Health Service, Centers for Disease Control and Prevention, National Institute for Occupational Safety and Health.

Heitbrink WA, Watkins DS [2001]. In-depth survey report: control technology for crystalline silica exposures in construction: the effect of exhaust flow rate upon the respirable dust emissions for tuck pointing operations and a preliminary evaluation of a ventilated tool for brick cutting at International Masonry Institute, Cascade, Maryland, March 20-24, April 17-21, May 8-11, July 10-14, September 11-15, and October 30-November 3, 2000. Cincinnati, OH: U.S. Department of Health and Human Services, Public Health Service, Centers for Disease Control and Prevention, National Institute for Occupational Safety and Health.

Hudock SD, Wurzelbacher SJ [2001]. Preliminary survey report: pre-intervention quantitative risk factor analysis for ship repair processes at Todd Pacific Shipyards Corporation, Seattle, Washington, April 12-13, 2000. Cincinnati, OH: U.S. Department of Health and Human Services, Public Health Service, Centers for Disease Control and Prevention, National Institute for Occupational Safety and Health.

Hudock SD, Wurzelbacher SJ [2001]. Preliminary survey report: pre-intervention quantitative risk factor analysis for ship construction processes at Marinette Marine Corporation Shipyard, Marinette, Wisconsin, May 8-9, 2000. Cincinnati, OH: U.S. Department of Health and Human Services, Public Health Service, Centers for Disease Control and Prevention, National Institute for Occupational Safety and Health.

Hudock SD, Wurzelbacher SJ [2001]. Interim survey report: recommendations for ergonomics interventions for ship construction processes at Marinette Marine Corporation Shipyard, Marinette, Wisconsin, May 8-9, 2000. Cincinnati, OH: U.S. Department of Health and Human Services, Public Health Service, Centers for Disease Control and Prevention, National Institute for Occupational Safety and Health.

Hudock SD, Wurzelbacher SJ, Johnston OE [2001]. Interim survey report: recommendations for ergonomics engineering interventions for ship construction processes at Jeffboat LLC, Jeffersonville, Indiana, November 9-10, 1999. Cincinnati, OH: U.S. Department of Health and Human Services, Public Health Service, Centers for Disease Control and Prevention, National Institute for Occupational Safety and Health. 
Marlow DA, Topmiller JL [2001]. Survey report: control technology evaluation for controlling worker exposure to asphalt fumes from roofing kettles: kettle operated using low fuming asphalt at Toledo Correctional Institute, Toledo, OH, September 28 and November 5-8, 1999.

Cincinnati, OH: U.S. Department of Health and Human Services, Public Health Service, Centers for Disease Control and Prevention, National Institute for Occupational Safety and Health.

Wurzelbacher SJ, Hudock SD [2001]. Interim survey report: recommendations for ergonomics interventions for ship repair processes at Todd Pacific Shipyards Corporation, Seattle, Washington, April 12-13, 2000. Cincinnati, OH: U.S. Department of Health and Human Services, Public Health Service, Centers for Disease Control and Prevention, National Institute for Occupational Safety and Health. 


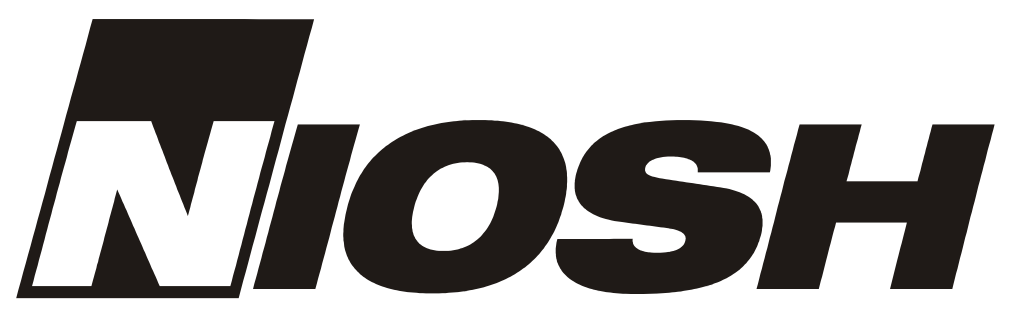

\section{Delivering on the Nation's Promise: Safety and health at work for all people Through research and prevention}

For information about occupational safety and health topics contact NIOSH at:

1-800-35-NIOSH (1-800-356-4674)

Fax: 513-533-8573

E-mail: pubstaft@cdc.gov

www.cdc.gov/niosh 